\title{
TÜRK HUKUKUNDA KORUNMAYA MUHTAÇ ÇOCUKLAR
}

\section{GIRIȘ :}

Asistan : Aydun ZEVKLILER

Sosyal etkenler çocuk psikolojisine, dolayısiyle çocuk suçluluğuna ve çocuk serseriliğine geniş ölçüde etkide bulunur. Bir sosyal birey olarak çocuğun içersinde yetiştił̆i aile, çocuğun ilişki kurduğu ilk ve en önemli çevredir. Çocuk, doğumundan belirli bir süre sonra başlamak üzere dıs çevreyi ve bu çevredeki süje ve olay. ları kendi yetenekleri ve içgüdüsü ile değerlendirmeye başlar. Fakat bu hal belirli bir süre sonra değişir ve çocuğun dış çevre hakkuidaki bu değerlendirmelerinde ailenin önemli rol oynadığı görülür. Aile içindeki düzen, şartlar ve eğitim tarzı çocuğun kişiliği ve dış çevre ile olan ilişkileri üzerinde geniş ölçüde etkide bulunur. Bu hal, çocuğun kişisel ve ekonomik serbestiye kavușma sına kadar, bazı hallerde belki bundan sonra da devam eder.

Çocukla aile arasındaki ilişkiler bu yönden çocuğun gelişmesinde ve kişilik kazanmasında da önemli rol oynar. Normal bir gelişme de, ancak normal bir aile düzeni içinde gerçekleşebilir. Çocuk suçluluğu bakımından aileler Tipik ve Atipik olmak üzere iki kısımda incelenir. Tipik aileler : Ana, baba ve çocuktan ibaret olup bunların bir arada yaşamasıyla meydana gelirler. Atipik aileler: Tipik ailedeki fertlerden başka diğer birtakım fertlerin de içinde bulunduğu veya tipik ailedeki fertlerden yani ana ve babadan birinin eksik olduğu veya üvey olduğu yahut ta çocuğu diğer akrabalarının büyütttüğü ailelerdir. Iște yukarıda değinilen normal bir kişisel gelişme de ancak tipik bir aile içinde mümkün olmaktadır. Bir çocuğun içinde bulunduğu aile, dıș görünüşü bakımından tamamen normal ve tipik olduğu halde iç bünye bakımından anormallikler gösterebilir. Özellikle bu anormallik aile fertleri arasındaki iliş̧kilerde göze çarpar. Ana baba çocuklarına karş olan ödevlerini yerine getirirlerken yetkilerini kötüye kullanarak veya çocuklarına karşı ilgisiz davranarak kendilerine düșen ödevi tam manasıla ifa etmezler. Bu durumda ana baba ço- 
cuklarının gerek maddi, gerek manevi yönden düşkün kalmalarına sebep olurlar. Bu şekilde hareket eden ana baba ile çocuk. ları arasındaki ilişkilerin normal oldugundan bahsedilemez.

Bu çocuklara nazaran durumu daha da kötü olan başka birtakım çocuklar da vardır. Öyle ki, bunlar bir ana babaya bile sahip değildirler ve her an için toplumun kötü etkenleri ile :karşı karșiya bulunmaktadırlar. Ana babası olmayan, ana babası belli olmayan, ve ana babası tarafından terkedilen çocukların durumu iște böyledir.

\section{TARİHÇE :}

Toplumun gelecekte sağlam temeller üzerinde yükselmesini sağlamak bakımından eski zamandanberi çeşitli toplumlar yukarıda bahsedilen durumda bulunan çocuklarla yakından ilgilenmișlerdir. Milâttan önceki çağlarda yașayan Sümerler'e ait kalıntılar üzerinde -özellikle «NİPPR» kasıları. yapılan kazılarda, daha sonra Mogolistanda bulunan yazitlardan von Le Cop'un doğu Tïrkistanda, TURFAN kesiminde bulduğu kayıtlarda çocukların korunması ile ilgili hüikümlere rastlanılmıştır.

Çocukların korunması meselesinin devlet tarafından ilk defa düzenli bir şekilde ele alınmasına tlhanlılar devletinde rastlanır. 12951304 yılları arasında hükümdarlık yapmış olan Gazan Małmut Han ülkedeki çocukların terbiye ve islâhı için yetimhaneler açmıştır. Bu yetimhanelerden her biri 100 tane çocuk barındırmakta idi. $\mathrm{Bu}$ türlü ilgilenmeler, yetimhaneler, barındırma yurtları, koruma yurtları, terbiye ve islah evleri açmak veya düşkựlere maddi yardımda bulunmaktan ileri gidememiştir. Halbuki bu meselenin esaslı bir șekilde kanunla düzenlenmesi gerekmekte idi. Iște bu zorunluluğun anlașılması ile daha sonraları bu yolda çahıșmalara girișilmiștir.

Türkiyede Cumhuriyetten sonra girișilen bu yoldaki çalıșma. lar 1926 yllinda Isviçreden reception (iktibas) yoluyla alınan Türk Medenî Kanununda bu hususta yer alan hükümlerle semeresini ver. miştir. Özellikle Medenî Kanunda küçüklerin korunması ile ilgili olarak getirilen hükümler bu konuda büyük bir adım teșkil etmek. tedir. Fakat Medenî Kanunun düzenleme sekli de bu hususta yeterli olmamaktadır. Çünkü Medenî Kanunda ana babası olan çocukların durumu geniș olarak düzenlenmekte, ana babası olmayan çocuklar hakkında ise vasî tayini ve vesayetle ilgili hükümler geti. rilmektedir. Halbuki ana ve babası olmayan çocukların durumu ile 
ilgili olarak o kadar çeşitli problemler meydana çıkmaktadır ki kanundaki düzenleme tarzı bütün bu meseleleri halletmeye yetmernek. tedir. Onun için özel mahiyetteki bir kanunla bu değișik meseleleri halletmek yerinde olacaktır. Netekim bu yoldaki çalışmalar 1949 yılında sonuçlanmış ve 5387 sayılı «Korunmaya Muhtaç Çocuklar Hakkındaki Kanun» çıkarılmıştır. Bu Kanun, yeterli olmadı̆̆ı için 1957 yllında 6972 sayılı Kanun çıkarılmış ve 5387 sayılı Kanunu yürürlükten kaldırılmıștır. 5387 sayıl Kanun hazırlanırken son derece dikkatli davranıldığı halde, mesele kanundan uygulama alanına döküldügüu anda kanunda nazara alınmayan aksak taraflar kendisini göstermiştir. Ilerde 6972 sayll Kanundan bahsederken 5387 sayılı Kanunun aksak görülen tarafları da ayrıca belirtilecektir. Herne kadar aksayan tarafları bulunsa da bu alanda ilk çıkarılan kanun olması bakımından 5387 sayılı Kanunun başarılı tarafları olmuştur. 6972 sayılı Kanun ise 5387 saylı Kanuna nazaran daha ileri seviyede düzenleme yollar getirmekle beraber onun da eksik bıraktığı birtakım hususlar vardır. Bunları 6972 sayılı Kanunu incelerken ayrıca belirteceğiz.

\section{$\S$ I- KORUNMAYA MUHTAÇ ÇOCUK TARIFI}

\section{I- MEDENI KANUN ILE 6972 SAYILI KANUNUN BİRLİKTE INCELENMESINDEN CIKAN TARIF :}

Giriş kısmında da belirtildiği gibi korunmaya muhtaç çocukların durumunu düzenlemeleri bakımından Medenî Kanun ve 6972 sayll Kanun birlikte incelenmeli ve «korunmaya muhtaç çocuk» hakkında bir tarif de ancak bundan sonra yapilmalidır.

6972 sayıl Kanun 1 inci maddesinde «korunmaya muhtaç çocuk» hakkında açıkça bir tarif yapmıștır. Gruplar halinde birtakım çocuklar șıklar halinde sayılmış ve sayılan bu çocuklara «korunmamaya muhtaç» denileceği belirtilmiştir (1). 6972 sayılı Kanunun

(1) 6972 sayll Kanunun I inci maddesi şöyle demektedir:

Beden, ruh ve ahlâk gelişmeleri tehlikede olup :

a - Ana ve babasız

b - Ana ve babası belli olmayan

c - Ana ve babası tarafindan terkedilen

d - Ana ve babaș tarafından ihmâl edilip fuhşa, dilenciliłge, alkollü içkileri veya uyușturucu maddeleri kullanmaya veya serseriliğe sürüklenmek tehlikesine maruz bulunan

Çocuklar (Korunmaya Muhtaç Çocuklar) denilir. 
sonraki maddelerinde ise bu gibi çocuklar hakkında ne gibi tedbirlerin alınması gerektiği belirtilmektedir.

Daha önce yürürlükte bulunan 5387 sayll Kanun bu şekilde açık bir tarif vermemiș, "Korunmaya muhtaç çocuklar»ı dc laylı ola. rak şu şekilde tarif etmiștir :

"Beden, ruh, ahlâk gelişmeleri tehlikede olup ana ve babasız, ana ve babası belli olmayan ve Türk Medenî Kanunu hükümlerine göre haklarında korunma tedbirleri alınmasında zaruret görülen çocukların mahkeme karariyla ve reşit oluncaya kadar bu kanunla belli edilen şartlar içinde bakılma ve yetiștirilerek meslek sahibi edilmeleri köy ihtiyar heyetleri, mahalli belediyeler, Sağhlk ve Sosyal Yardım Bakanlı̆̆̆ ve Milli Eğitim Bakanlığınca sağfanır.»

5387 sayılı Kanunda açk olarak göze çarpan tarif bakımından olan bu farklliktan başka diğer bir farklılık ta Korunmaya Muhtaç Çocuklar Hakkındaki Kanunun Medenî Kanunla olan bağlantısin belirtmek bakımındandır. Tarifte de belirtildiği gibi 5387 sayıl Kanunun 1 inci maddesinde, «... ve Türk Medenî Kanunu hükümlerine göre haklarında korunma tedbirleri alınmasında zaruret görülen...» denerek bu kanunun Medenî Kanunla birlikte uygulanacağı ortaya konuluyordu. Böylelikle korunmaya muhtaç çocuklar hakknndaki bir meselede hakim Medenî Kanun ile Korunmaya muhtaç çocuklar hakkındaki kanunu birlikte inceleyecek ve gerektiŏginde korunmaya muhtą̧ çocuklar hakkında karşılaştı ğ bir boşluğu Medenî Kanun hükümleri ile dolduracaktı. Zaten Hukuk Tekniği bakımından, hakimin kanun boşluğunu doldururken normal olarak yapacağı da budur. Fakat 5387 sayılı Kanunda açı olarak belir. tilmesi durumu daha da kuvvetlendirmektedir. 6972 sayıl Kanun karşısında dahi durum böyledir. Çünkui 6972 sayılı Kanun tek başına uygulanacak olursa çözüm yolu bulunamıyacak birtakım hallerle karși karșıya kalımı. 6972 sayılı Kanunun hükümlerinden hareket edilecek olursa ana babası olan çocuklar hakkında korunma tedbirleri alınabilmesi için bunların ana babaları tarafindan, fuhșa, dilenciliğe, alkollü içkileri ve uyuşturucu maddeleri kullanmaya veya serseriliğe sürüklenmek tehlikesine maruz bırakılmaları gerekir (2).

Aslında bir ana baba bu gibi davranıșlarda bulunmadığı halde çocuğuna karșı olan ödevlerini yerine getiremiyorsa (acze düșme),

(2) Bu hususta bk. sh. 175 dip notu, d şlkkı 
mahcursa, çocuğu üzerindeki nüfuzunu suiistimal ediyorsa (3) bu çocuk hakkında 6972 sayılı Kanun hükümlerine göre korunma tedbirleri alınamyacak demektir ki bu hiç te dogru olmayan bir sonuçtur. Bưnun içindir ki Medenî Kanun da 6972 sayılı Kanunla birlikte uygulanmalıdrr. Böylelikle 6972 saylh Kanunda düzenlenmiyen hususlarda Medenî Kanun hükümleri uygulanacak ve bu alanda bir boşluk kalmiyacaktır.

Burada şöyle bir soru da hatıra gelebilir : Korunmaya muhtaç çocuklar hakkında sadece Medenî Kanunun uygulanması yeterli midir? Medenî Kanunla birlikte 6972 sayll Kanunun da uygulanması gerekli midir? Bu soruya da ayni şekilde, yani her iki kanunun da birlikte uygulanması gerektiłi șeklinde cevap vermelidir. Çünküi ileride görüleceği üzere korunma ile ilgili olağanüstü haller. de alınacak korunma tedbirleri arasında çocuğa vasî veya kayyım tayini ve velayetin nez'i tedbirleri de mevcuttur.

Velâyetin nez'i bahse konu olan hallerde çocuğun ana babası vardır, yani velâyet altındadır. Halbuki korunmaya muhtaç çocukların bïyük bir kısmı ana babadan, yani veliden yoksundur (4). Bu durum karşısında velâyetin nez'i tedbiri bu çocuklar için bahis konusu olamaz. Medenî Kanunda da bu gibi çocuklar tamamen bir tarafa bırakılmış değillerdir. Ana babası olmayan çocuklara Medenî Kanun madde 354 c. 1 e göre vasi tayin edilir (5). Kendisine vasî tayin edilen çocuğun şahsı ve malları ile ilgilenecek, çocuğa kar\$̧ı gerekli ihtimamı gösterecek olan kişi vasidir. Bu onun için bir kamu görevidir ve görevden dolayı vasî gerekli makamlara hesap vermek zorundadır (6). Vasinin çocuğun mallarnna gerekli ihtimamı gösterirken çocuğun ihtiyaçları için gerekli olan harcamaları da çocuğun mamelekinden yapacaktır. Fakat çocü̆un serveti ve masraflarına katılacak ana babası da yoksa bu durumda sadece Medenî Kanun hükümlerinden hareket ederek çocuğa bir vasî ve kayyım tayini bu yönden çocuğa hiç bir fayda șağlamayacaktır. Böyle bir çocuğun iașe ve ibatesini, eğitim masraflarınt kimin karşılayacă̆ı sorusuna 6972 sayll Kanun cevap vermektedir (7).

(3) Bu hususta bk. Medeni Kanun 273 ve sonraki maddeleri

(4) Bu hususta fazla bilgi için bk. Korummaya muhtaç çocuk tarifinin unsurları, Ozzel şartlar sh. 181 vd.

(5) Fazla bilgi için bk. AKINTÜK, Turgut: Aile Hukuku Dersleri, Ank. 1967, sh. 365 vd.

(6) Bk. Akıntürk, Turgut: a.g.e., sh. 385.

(7) Bk. 6972 sayll Kanun 1 inci ve sonraki maddeleri. 
Görülüyor ki korunmaya muhtaç çocuklar konusunda Medenî Kanunun ya da 6972 sayılı Kanunun tek başına uygulanmasıyla korunma ile ilgili meseleleri halle imkân yoktur. Gerek kanun tekniği, gerekse yukarıda belirttiğimiz sakıncalardan dolayı her iki kanunun da birlikte incelenmesi gerekir. Korunmaya muhtaç çocukların tarifini yaparken de bu noktadan hareke! ederek her iki kanun da göz önünde tutularak Korunmaya muhtaç çocuklar, korunmanın unsur ve şartları bu suretle tanımlanmak gerekir.

\section{A-Korunmaya Muhtą̧ Çocuklar :}

Bir çocuğun korunmaya muhtaç çocuk olabilmesinin iki şartı vardır. Bu şartlar genel ve özel olmak üzere iki kategoride toplanmaktadır.

\section{1 - Genel Șartlar :}

Genel şartların korunmaya muhtaç her çocukta mutlaka bulunması gereklidir. Bu şartlar, Küçüklïk ve beden, ruhî, ahlâkî ve fikrî gelișmenin tehlikede olmasıdır.

\section{a- Küçük Olmak :}

Korunmaya muhtaç çocuklar hakkındaki 6972 sayılı Kanun korunmaya muhtaç çocuklarla ilgili olarak «...reşit oluncaya kadar ...» tedbir alınacağını belirtmektedir (KMÇHK m. 1) Medenî Kanunun 273 ve sonraki maddeleri de velâyet altındaki çocukları yani küçükleri düzenlemektedir. $O$ halde bir çocuğun korunmaya muhtaç bir çocuk sayılabilmesi için en önemli ve bașta gelen sart bu çocuğun küicük olması dır. Başka bir deyişle çocuk rüșde ermemiş olmalıdır. Medenî Hukuk açısından kişilerin iki ehliyeti vardir: Hak ehliyeti ve Fiil ehliyeti.

Herkes, doğduğ̆u anda Hak ehliyetine sahiptir. Bu yönden sağ. lam-sakat, büyük-küçük, kadın-erkek, yerli-yabancı ayrımları yapılmadan her kiși haklara ve borçlara sahip olma ehliyetine sahiptir. Kișilerin sahip oldukları hakları bizzat kendilerinin kullanabilmeleri, kendi fiilleri ile kendilerini alacaklı ve borçlu durumuna sokabilmeleri için birtakım şartlar aranmaktadır ki ancak bu şartların tamam olması ile kişi, fiil ehliyetine sahip sayllır. Bu şartlar: 1-Mümeyyiz olmak, 2-Reşit olmak, 3-Mahcur olmamaktır (8).

(8) Fazla bilgi için bk. AKtPEK, Jale G.: Türk Medeni Hukuku, Şahsın Hukuku, C. I, cüz 2, Ank. 1961, sh. 53. vd. 
İște bu şartlardan reșit olmak yani onsekiz yaşım bitirmiş bulunmak ta diğer şartlar gibi kişinin kendi muamelelerini yalnızca kendi başına yapabilmesi için gerekli sayılmıştır. Eğer kiși bu şarta sahip değilse, yani rüşde ermemiș ise, başka bir deyimle küçük ise (9) fiil ehliyeti de tam değildir. Kişinin temyiz kudretine sahip olması durumu değiștirmez.

Gérek Medenî Kanun ve gerekse 6972 sayıli Kanun korunmaya muhtaç çocukların reşit oluncaya kadar korunacaklarını belirtmektedir. O halde en önemli şart ilk bașta küçük olmaktır.

b- Beden, ruh, ahlâk ve fikrî gelişme yönünden tehlikede bulunmak :

\section{aa- Bedeni gelişmenin tehlikede bulunması :}

Bundan maksat çocuğun fiziki bünyesi, dıș görünüşüi bakımından gelişmesinin tehlikede olmasıdır. Kişilerin doğumlarından itibaren belirli bir yaşa kadar zamanla orantılı bir büyüme ve gelișme tempoları ve seviyeleri vardir. Tip ilmince hazırlanan belirli cetvellere bakarak belirli bir yaştaki çocuğun ağırlığının, boyunun, diğer vücut ölçülerinin ne kadar olması gerektiği kolayca söylcnebilmektedir. Ancak șunu da hemnen söylemek gerekir ki bu belirli gelişme ve büyüme oranı, normal şartlar altında gelișen ve büyüyen çocuklar için bahis konusudur. Eğer çocuğun normal gelişme şartları sağlanamaz veya normal şekilde gelișmesine çeșitli șekillerde engel olunursa bu gibi çocuklarnn beden gelişmeleri de normal olmayacaktır. Örneğin: çocuk ağır hayat șartları altında büyük bir insan gibi çalışturılır, ağır maddi fiiller ve işkenceyle karşı karşıya bırakılır veya gıda yetersizlikleri yüzünden yeteri kadar gelişemez. Bu gün genellikle kabul edildiği üzere; çocuklar belirli bir ya- . şa gelmeden çok ağır işlerle uğraşmak zorunda kahırlarsa bedenî gelişmeleri de aksamakta, belirli bir seviyeden yukarı çıamamaktadır. Gıda yönünden mevcut olan yetersizlikler de ayni sonuçları doğurmaktadır. İște bu șekilde bedeni gelișmeleri sakıncalı olan çocuklar hakkında korunma tedbirleri alınacaktır. (KMÇHK m. 1)

$\mathrm{bb}-$ Ruhî gelişmenin tehlikede bulunması :

Bundan maksat bedenî gelișmenin normal veya anormal olması nazara alınmaksızın manevî ve ruhî bünyesi gelişme bakımın.

(9) Fazla bilgi için bk: VeltdedeoĞLU, H. V.: Türk Medeni Hukuku, C. II, cüz 1, Aile Hukuku, Ist. 1966 sh. 335 vd, ayrica AKINTURK, Turgut : a.g.e., sh. $284 \mathrm{vd}$. 
dan eksik ve geri olan veya değişiklik gösteren küçüklerdir. Bu gibi çocuklar ya büyük bir ruhî çöküntü içindedirler veya değişik ruhî komplekslerin tesiri altında bulunmaktadırlar. Tıp ilminin verilerinden faydalanılarak bu gibi durumda olanların ruhî gelişmesinin anormallik gösterdiği kat'i olarak tespit edilmiștir. Bu gibi küçükler ruhî yönden birtakım fobilere veya halisünasyonlara sahiptirler ve devaml olarak bunların etkisi altindadırlar. Bu unsurlar ya yavaş yavaş küçüğü etkileyerek zaman geçtikçe ruhî yapısın. da anormallikler meydana getirmekte, veyahut ta çocuğa ancak belirli bir anda ve belirli olaylar karșısında etkide bulunmakta ve çocuğun ruhî yapısında birdenbire meydana gelen deģisisikliklere yol açmaktadır. Örneğin: daima ağır hakaret ve sözlere maruz kalan, herkes tarafından hor görülen, itilip kakılan, ya da ana babaya sahip olmayan çocuklar böyledir. Ana babaya sahip olmayan çocuklar bu yokluk hissi ile daima manevî bir acı duyarlar. Bunun tesiri ile de șuur altında kendi psikolojik durumu ve iç alemi ile uygun bir ortam yaraturlar.

\section{cc- Ahlâkî gelișmenin tehlikede bulunması :}

Bu nisbî ve subjektif bir șartır. Çünkü ahlâk anlayışı zamana göre değiștiği gibi ayni zaman içersinde başka başka yerlerde de değişiklik arzeder. Hatta belirli bir memleket içinde, değișik bölgelerdeki görüşsler dahi farklı olabilir. Onun için ahlâki durum hakkında kesin bir sey söyleyip misaller vermek doğru değildir. Bu alanda hakime geniș bir takdir hakkı tanınmalıdır. Netekim bu hususta kanunlarımız da hakimlere gerekli takdir yetkisini tanımıs. lardır. Bu hususta umumî birer hüküm mahiyetinde olan Borçlar Kanunu 19 ve 20 nci maddeleri, icabında korunmaya muhtaç çocuklar hakkında da uygulanır. Bu maddelerde ahlâk ve adaba aykırı mukavelelerin hükümsüz olduğu açıkca belirtilmektedir. Demek ki korunmaya muhtaç bir çocuğu ilgilendiren ve ahlâk ve adaba aykırı olan mukaveleler hükümsüz sayılacaktır. Hâkim önüne gelen meselede içinde bulunduğu çevrenin ahlâk anlayıșını ve ku. rallarm da göz önüne alarak karar verecektir.

\section{cld- Fikrî gelişmenin tehlikede bulunması :}

Bundan maksat normal bir insanın sahip olması gereken fikrî yetenck ve gelișmeye sahip olamamakdır. Bu özellik bir ferdin bir yeteneği olduğu kadar ayni zamanda hakkıdır da. Her fert belirli bir küitür seviyesinde bilgili ve normal fikrî yeteneğe sahip olarak yetişsmek hakkına sahiptir. Bir memleketin geleceği bakımın- 
dan o memleketin çocuklarn üzerindeki ilgilenme ne oranda olursa o memleket o oranda geleceğini garanti altına almıs olur. Bu husus o kadar önemlidir ki "Çocuk Hakları" adı altında apayr bir bilim kolunun doğmasına sebep olmuştur (10).

Hatta daha ileri gidilerek milletlerarası alanda da bu husus düzenlenmiştir (11).

Eğer çocuk birtakım biyolojik anormallikler veya ekonomik yetersizlikler sebebiyle belirli bir seviyedeki fikri gelișmeye ulaşamamış ise bunu sağllyacak tedbirleri almak ilk bașta ana babanın görevleri içindedir (12). Ancak ana babanın bunu yapmaktan aciz oldukları veya yapamadıkları hallerde bu ödevin kimlere düşeceği ilerde tedbirler bahsinde incelenecektir.

2- Özel Sartlar :

Bu şartlar 6972 sayll Kanunun 1 inci maddesinde Korunmaya Muhtaç çocuklar tarifi yapılırken şıklar halinde sayılmıştır. Bir çocuğun korunmaya muhtaç çocuk addedilebilmesi için bu genel şartlardan birine de sahip olması gerekir. Başka bir deyișle bu özel șartlardan biri mutlaka genel şartlarla birlikte kendisinde bulunmalıdır.

\section{a- Ana ve babasız olmak:}

Bundan maksat çocuğun evlilik içinde doğması ve fakat sonradan ölüm, gaiplik gibi sebeplerle hem anasını hem de babasını kaybetmis bulunması ve kendisine kanunen bakmakla mükellef kimselerinin bulunmamasıdır. Bir kere bu çocuklar muteber bir evlilik içinde doğmuşlardır; fakat her nasılsa sonradan ya tabii olarak, yahut ta bir kaza netjcesi ana ve babaları ölmüş veya gaip olmuștur (13).

6972 sayrlı Kanunun 1 inci maddesinden de anlaşılacağı gibi küçïgüin hem anadan ve hem de babadan yoksun bulunması ge-

(10) Fazla bilgi için bk. SAPMAZLI, Hüseyin: Çocuk haklan ve Himaye Müiesseseleri, Ank. 1943.

(11) UNESCO nun faaliyetleri arasında "Körlerin eğitimi ve özel eğitime muhtaç çocukların eğitimi» de yer alır; ayrıca bu teşkilâta bağlı olarak kurulan UNICEF (Birleşmiş millletler çocuklara yardım teşkil-

t1) nın başlıca ilgilenme konusunu bu gibi çocuklar teşkil eder.

(12) Medeni Kanun 273 ve sonrasi.

(13) 6972 sayll Kanunda ana babanın gaip olması halinden bahsedilmemektedir. Fakat ana babanin gaip olması halini de burada incelemek gerekir. 
rekir. Aksi halde, yani ana babadan yalnı birisine sahip olmama halinde, küçüğuin durumu genel şartlara uysa da - beden, ruh, ahlâk ve fikri bakımdan gelişmesinin tehlikede olması - 6972 sayılı Kanuna göre hakkında korunma tedbiri alınamıyacaktır.

Bu durumdaki küiçükler hakkında Medenî Kanun hükümlerinin uygulanacağı ileri sürülebilirse de kanaatimizce bunun uygulanması mümkün olmayacaktır. Her ne kadar Medenî Kanunun iigili hükümlerine göre bir kü̧̧ük hakkında tedbir alınabilmesi için «bedeni ve fikrî gelişmesinin tehlikede olması veya manen metruk bir halde bulunması» gerekirse de aslinda "Manen metruk bulunmak» 6972 sayılı Kanundaki "Ruhî gelişmesinin tehlikede bulunması» karş̧lığıdır. Fakat, fazladan olarak 6972 sayılı Kanunda «Ahlâkî̀ gelişmenin tehlikede olması" ndan bahsedilmektedir ki buna Medenî Kanunda yer verilmemiștir. Medenî Kanundaki «Mânen metruk halde bulunma» kavramı içine "Ahlâkî gelișmenin tehlike-' de olması» $n_{1}$ sokmaya imkân yoktur. Çünkü bir küçük ahlâken normal bir şekilde yetişmekte ve kendisine gerekli ahlâkî terbiye verilmekte olduğu halde manen terkedilmiş, kendisine hiç bir şekilde șefkat ve sevgi gösterilmemiş olabilir.

6972 sayılı Kanun ana ve babası bulunmayan çocuklardan bahsetmiş̧tir. Ana ve babasmdan sadece birisine sahip olup ta ahlâkî gelişmesi tehlikede bulunan küçüğün durumu ne olacaktır? Ana ve babadan sadece biri mevcut olan çocuk hakkında Medenî Kanun hükümlerine göre tedbir alnabilir, fakat Medenî Kanunda «Ahlâkî gelişmenin tehlikede bulunması" halinden bahsedilmemiştir. Bunun için 6972 saylı Kanunun 1 inci maddesine bir hüküm eklenerek ana babadan birine sahip olmama hali de düzenlenmelidir. Bı şık içinde daha önce belirtildiği gibi, «Mânen metruk halde bulunma»yl, "Ahlâkî gelişmenin tehlikede olması" halinin karşılığı olarak ele almak mümkün değildir (1). Meselâ bir fahișe anne çocuğunun bedenî, fikrî ve manevî her türlü gelişme yeterliliklerini sağlayıp ona manen her türlï yakınlığı gösterdiği halde ve hatta küçiuğün de kendi durumundan memnun olmasına rağmen çocuğun fahișe olan annesi yanında yetișip büyümesi ahlâken mahsurlu de. gildir denilebilir mi?

Bu yüzden 6972 sayıl Kanuna yukarıda belirttiğimiz gibi ana babadan birisinin bulunmaması halini düzenleyen bir hüküm eklenebilir. 


\section{b- Ana babanin belli olmaması:}

Ana ve babalarnnın kim olduğu bilinmeyen bütün çocuklar bu gruba girerler.

aa- Ana babanın başlangıçtan beri belli olmaması :

Bunlar ana babası tarafindan cami, belediye gibi yerlere, kapı önlerine, tenha sokaklara ve buna benzer yerlere gizlice bırakılmıș olan ve ana babası da bir türlü tespit edilemiyen çocuklardır. Yahut ta çocuk evlilik dışında dünyaya gelmiştir ve henüz tabîi baba ile arasında babalık bağı, yani gayrisahih nesep meydana gelmemiştir ve anasının da kim olduğu bilinmemektedir.

\section{bb- Ana babanın sonradan belirsiz hale gelmesi :}

Yetimhanelere veya müesseselere bırakılan çocukların ana ve babalarının kimliğ̈i bu müesseselerce imkân nisbetinde tespit edilerek kaydedilmektedir. Fakat her naslsa bu kayitlar sonradan herhangi bir sebeple yokolmaktadır. Ve çocuğun kime ait olduğuna dair başkaca bir delil de yoktur. Yahut çocuk bir kişiye veya aileye verilmiştir, bu kișiler de sonradan ölmüş̧tür ve onlardan bașka da çocuğun kine ait olduğunu bilen yoktur.

Iște bütün bu çocuklar hakkında genel şartlara uyduğu hallerde korunma tedbirleri alınacaktır.

c-- Ana ve baba tarafından terkedilmek :

Bundan maksat, ana ve babanın velâyetten doğan asgarî vazifelerini yapmamak niyetiyle kasden veya bu vazifeleri yapmakta maddî ve manevî aciz göstermek suretiyle çocukla olan ilișkilerindeki çözülmedir. 6972 sayllı Kanuna uygun olarak çıkarılan yönetmeliğin 1 inci maddesinde de bunun böyle anlaşılması gerektiği belirtilmektedir. Medenî Kanun 274 de de ayni durum etraflı olarak düzenlenmiş̦tir. Medenî Kanunun adı geçen maddesinde; «ana babanın çocuğa karşı haiz oldukları vazifeleri ihmal etmeleri", «ana babanın velâyeti ifadan aciz olmaları" şılarında ayni durum ele alınmaktadır. Bu durumların ne gibi hal tarzlarına bağlandığı ileride tedbirler bahsinde görülecektir.

d- Ana babası tarafindan ihmal sedilmek :

Ana baba tarafından ihmal edilmek demek, çocuğun fuhşa, dileciliğe, alkollü iş̧̧ileri ve uyuşturucu maddeleri kullanmaya veya serserilik tehlikesine sürüklenmeye maruz bırakılması demektir. Bir önceki şıkta da ana babanın küçüği ihmalinden bahsedilmiş. 
tir. Fakat oradaki ihmal ana, babanun küçük üzerindeki vazifelerini yerine getirmemesinden doğan bir ihmaldir. Örneğin, çocuğun bakm ve beslenmesini ihmal etmek gibi. Halbuki burada bahse konu olan ihmal, çocuğun fuhşa, dilenciliğe, alkollü içkileri ve uyușturucu maddeleri kullanmaya veya serseriliğe sürüklenmesine sebep olacak şekilde vazifelerini ihmal etmeleridir.

Sonuç olarak korunmaya muhtaç çocukları şöylece tarif edebiliriz : Bedenî, ruhî, ahlâkî ve fikrî gelișmeleri tehlikede oup ta ana babası olmayan, ana babası tarafından terkedilen küçüklerle ana babası mevcut olmakla beraber onlar tarafından fuhșa, dilenciliğe, alkollui içkileri ve uyuştırucu maddeleri kullanma alışkanlığına veya serseriliğe itilen veya ana babanın kendisine karșı olan vazifelerini yerine getirmekten aciz bulunduğu veya kasten yerine getirmemeleri dolayısıyla ana babadan velâyet hakkı nez'edilen çocuklar korunmaya muhtaç çocuklardır.

\section{$\S$ II- KORUNMA TEDBIRLERI}

Korunma tedbirlerinin alınmasiyla ilgili olarak iki safha var. dır. Bunlardan biri bu tedbirlerin almmasindan önceki safha, diğeri de tedbirler safhasıdır.

\section{I- KORUNMA TEDBIRLERINIIN ALINMASINDAN ÖNCEKİ SAFHA :}

Korunmaya muhtaç bir çocuğun varliğını haber alan zabıta, belediye ve devlet memurları durumu derhal mahallin en yüksek mülkî amirine bildirmekle mükelleftirler (KMÇHK m. 2). Ayrıca bu Kanunun tatbiki ile ilgili olarak çıkarılan "Korunmaya muhtaç çocuklar hakkındaki 6972 sayılı Kanunla ilgili yönetmelik» e göre, korunmaya muhtaç çocukların bulunup ortaya çıkarılması için mülkiye amirleri gereken bütün tedbirleri alırlar. Yine ayni yönetmeliğe göre, zabıta, belediye ve devlet memurlarından başka, böyle bir durumdan haberdar olan muhtarlar veya herhangi bir vatandaş dahi durumu derhal en yüksek mahallî mülkî amire bildirecektir (14). Zabıta, belediye ve devlet memurları gerek gö-

(14) Bu hususta bk. KMÇHK. ile ilgili yönetmelik hükümleri. 
revlerini yaparken ve gerekse görevleri dışında herhangi bir vatandaş gibi - her iki halde de - durumu mülkî amire bildirmekle görevlidirler. Mahallî mülkî amire bildirme işi yazılı veya sözlü olabilir. Sözlü ihbarda bulunulmuşsa ihbarın yapıldığı memur durumu tutanakla tespit edecektir. Kendisine ihbar yaplan mahallì mülkî amir, çocuk hakkında gerekli bilgilerin toplanması için harekete geçer. Bu arada nüfus dairesinden çocuğun nüfus kaydı, maliye, tapu ve hususî muhasebeden çocuğun belirli bir gelirinin olup olmadığı, eğer varsa ne şekilde ve ne kadar olduğu, ayrıca muhtar veya polisten çocuğun aile ve kișisel durumu da sorulur. Mahallî mülkî amir bu görevleri sıfır ile altı yaş arasındaki çocuklar için il veya ilçelerdeki Sağlık ve Sosyal Yardım Bakanlığı temsilcilerine, yedi ile onsekiz yaş arasındaki çocuklar için il veya ilçelerdeki Millî Eğitim Bakanlığı temsilcilerine verir. Bu makamlar yukarıda belirtilen kaynaklardan elde ettikleri bilgilerin örneğini çıararak fişe işler ve çocuk hakkında hazırlanmakta olan dosyaya ekler. Ayrıca bu makamlar, hakkında ihbar yapılan çocugun korunmaya muhtaç olup olmadikları hususunda da araștırma yaparlar. Sonunda çocukla ilgili bir dosya hazırlanarak mahallî mülkî amire verilir. Haklarında korunma tedbirleri alınması gerekli olan çocukların dosyaları acele olarak hazırlanıp mahallî mülkî amire teslim edilmek gerekir. Ayrıca 6972 sayılı Kanunla ilgili yönetmelik korunmaya muhtaç çocukların taranması ve bulunup çkarılması için illerde Milli Eğitim ve Sağhı ve Sosyal Yardım müdürlükleri ile bunların ilçelerdeki teşkilâtlarının her türlü tedbirleri alacaklarını bildirmektedir. Fakat uygulamada bu alanda herhangi bir faaliyete rastlanmamaktadır. Ulaşılmak istenen maksadın elde edilmesi için bu arama tarama ve tespit işinin önemle ele alınması gerekir.

Çocuk hakkındaki dosya kendisine verilen mahallî mülkî amir bu dosyayı çocuk hakkunda korunma tedbiri alınması talebiyle birlikte o mahallin sulh hukuk hâkimliğine gönderir. Hâkim, dosyayı inceledikten sonra gerekli görürse çocuk hakkında tedbir kararı verecek ve ne gibi tedbir alınması gerektiğini de tayin edecektir. Hâkìm, bunu yaparken çocuk hakkında hazırlanan dosyadaki büitün vesikaları inceleyip, çocuk hakkında hangi tedbirin alınmasında fayda olduğunu takdir hakkını kullanarak tayin edecektir. Ayrıca hâkim, kararından, çocuğun korunmasını gerektiren durumun ne olduğunu, ana babanın veya bunlardan birisinin veya çocuğa kanunen bakmakla yükümlüi olan kişilerin çocuğun bakımına iştirak paylarnı, çocuğun malları varsa bunun nasıl idare ve muhafaza 
edileceğini, velâyetin kaldırrlmasının veya vasi tayininin gerekip gerekmediğini de belirtir.

Çocuk hakkında bir müesseseye yerleştirilme kararı alınmışsa bu tedbir kararnndan sonra bütün vesikalarla birlikte dosya ait olduğu birliğe yani o bölgenin bağlı olduğu birliğe gönderilir. Çocuğun dahil olduğu birlik çocuğu, ilgili bakanlıklar adına kendilerine en uygun düșecek olan müesseselere yerleştirir.

Birlik yeni deliller elde ederse bunları ileri sürerek mahkemeden kararın kaldırılmasın veya düzeltilmesini isteyebilir.

Birliklerin bulundukları yerlerde hakkında karar alınan çocuklar için elverişli müesseseler yoksa birlik, gerekli tedbirlerin alın. masını ilgili bakanlıklardan ister.

Şimdiye kadar incelediğimiz durum, hakkında acele korunma tedbiri alınması gerekmeyen küçükler hakkındadır. Bir de haklarında acele korunma tedbirleri alınması gereken çocuklar vardır. Bu çocuklar hakkında mahkeme kararı alınmcaya kadar mahallî en yüksek mülkî amirin emri ile 6972 sayılı Kanuna göre kurulan müesseselerden birine, bu gibi müesseseler yoksa uygun aileler yanına veya hayır müesseselerine yerleştirilirler. Haklarında geçici tedbir alınan bu gibi çocukların bütün masrafları ilgili birliklerce karșılanır. Ayrıca bu gibi çocukların korunma kararı alınmasıyla ilgili işlemleri en geç bir ay içinde tamamlatılır.

Geçici tedbirler, hâkimin tedbir alınması gerekmediği yolundaki karan ile veya tedbir alınması gerekiyorsa verilecek asıl tedbir kararı ile sona erer. Çocuk hakkında bașka türlü bir tedbir öngörüldüğti takdirde çocuk müesseseden alınıp hakkında alınan tedbir uygulanmaya bașlanır.

\section{II- KORUNMA TEDBİRLERI SAFHASI :}

A- Genel tedbirler :

Genel tedbirler, hakim tarafindan alınan ve devaml olan tedbirlerdir. Bu tedbirlerin neler olduğu 6972 sayılı Kanun ile Medenî Kanunda gösterilmiştir. Hâkim bu tedbirlerden hangisinin alın. ması gerektiựini durumu, çocuğın özelliklerini ve eldeki imkânları göz önünde tutarak tayin eder. 
1- Çocuğun bir aile yanına yerleștirilmesi :

Kendisinden tedbir kararı verilmesi talep edilen hâkim, çocuk hakkında hazırlanan dosyayı ve o bölgedeki birliklerin imkânları$\mathrm{n}_{1}$ inceleyerek, yetişmesi ve eğitilmesi yönünden daha uygunsa çocuğu, bir aile yanına yerleștirmeye karar verecektir. Çocuk mevcut müesseselere intibak edemiyecek bir psikolojik yapıya sahipse ve çocuğun bir aile yanına yerleștirilmesi kendisi için daha uygun olacaksa çocuk aile yanına yerleştirilir. Aslında çocuğun bir aile yanına yerleștirilmesi 6972 saylı Kanunun gayesine daha uygundur. Korunmaya muhtaç bir çocuk hakkında korunma tedbiri alınıp bir yere yerleștirilirken dikkat edilecek șey, çocuğun burada kendisini asıl ana babasının yanında imiş gibi hissetmesi, çocuğa asıl ana baba gibi şefkatle davranılması ana babadan yoksun oldugunun unutturularak ona sağlam bir benlik aşılanması ve toplum için yararı bir kişi olarak yetiştirilmesini sağlamaktır. Bu gayeye en uygun düşen tedbir çeşidi de çocuğun bir aile yanına yerleştirilmesidir. Çocuğun bir aile yanına yerleştirilmesi gerek Medenî Kanun (m. 273) ve gerekse 6972 sayılı Kanunda öngörülmüștür (m. 3).

Bir aile yanına yerleștirilmesine karar verilen çocuklar bu iși başarabilecek ehil aileler yanına verilirler. Çocukların bu aileler yanında kalması geçici veya sürekli olabilir. Çocuk aile yanına yerleștirilirken birlik ile aile arasında yazıl bir sözleşme yapılır. Bu sözleşmede ailenin çocuklara ne şekilde bakacağı, onları ne şekilde yetiştirip eg̣iteceği kararlaştırılır. Çocuğun yanına yerleştirildiği aileler bu çocuklarm kabiliyet derecelerine göre genel meslek eğitimlerini sağlamakla ve onları eğitmekle yükümlüdürler. Bu gibi çocukların bakım ve yetiştirilmeleri ile ilgili her türlü harcama. lar birlik encümeni tarafından tespit edilen miktarda her yıl çocuklarm vanına yerleștirildikleri ailelere verilir.

Korunmaya muhtaç çocuklar korunma ve yerleştirilme maksatları dıșında hiç bir şekilde hizmetçi, dadı vs. olarak aileleı yanina verilemezler.

Yalnız bu noktada istisnâ̂ olarak şunu da incelemek gerekir. Bu husus, müesseseler yerleștirilen çocukların buradan evlât edinilmek üzere herhangi bir aile tarafından alınıp alınamayacağıdır. 6972 sayılı Kanunla ilgili yönetmelik her ne kadar bu gibi çocukların korunma ve yetiştirilme maksatları dışında aileler tarafından alınamıyacağını belirtmekte ise de çocukların evlât edinilebilmele- 
rini bu hüküm dışında tutmak gerekir. Nitekim tatbikatta da öyle yapılmakta ev bu gibi çocuklar aileler tarafindan evlât edinilebilmektedirler. Hatta bu hususta 5387 saylı eski Kanunda bir hüküm vardı ve bu çocukların aileler tarafından evlât edinilebilecekleri bildirilmekte idi. Aslında bu gibi çocukların evlât edinilmeleri, elde edilmek istenen gayeyi sağlamak bakımından daha elverişlidir. Bir aile tarafından evlât edinilen çocuk, $o$ aile içinde her bakımdan kendi öz ailesinden farksız olacaktır. Bu şekilde evlât edinilen çocukların bakım ve yetiştirilme masrafları artık birlik. lerce değil, kendilerini evlât edinen kimseler tarafından sağlanacaktır. Medenî Kanun hükümleri gereğince, evlâtlık evlât edinenin sahih nesepli füruğu sayılacak, onun soyadını tașıyacak, mi. rasçısı olacak ve velâyetten doğan ödevler bundan böyle evlât edinene düşecektir (MK m, 257) (15). Artık bu durumda birliklerin çocuğın masraflarını ödeme ve durumunu kontrol diye bir fonk. siyonları olmayacaktır.

Çocukların korunma tedbirlerinden olmak üzere başlangıçta aile yamna yerleștirilmelerine gelince, çocukların yanlarına yerleș. tirildikleri bu gibi ailelere KORUYUCU AÍLELER denilmektedir. Bu aileler çocuğu gerektiği kadar yetiştirecek ve eğitecek yeterliklere sahip olmalıdır. Çocuğun yanlarına yerleştirildiği aileler çocuğa öz ana babaları gibi davranacaklar, ona ana babadan yoksun oldığunu unutturacaklar ve onu topluma yararlı bir kişi olarak yetiștireceklerdir. Ailelerin bu çocuklan koruma ve yetiștirme gayesi dışına çıkacak şekilde istismara hakları yoktur. 6972 sayılı Kanunla ilgili yönetmelikte de bu açıkça belirtilmektedir. Çocuklar bu aileler yanına yetiștirilmek maksadıyla verilmekte fakat sonradan aileler tarafından hizmetçi ve uşak gibi çalıștırılmakta gerek bedeni, gerek ruhî ve fikrî ve gerekse meslekî eğitimleri yönünden ilgisiz davranılmakta veya istismar edilmektedirler. Bunu önlemek için birlik. ler çocukların aileler yanındaki durumlarını sık sık kontrol etmek üzere teșkilâtlarını genişletmeli ve gerekli tedbirleri almalı. dirlar.

Bu çocukların yanlarına verilecekleri ailelerde aranılan bazı özellikler vardır.

Bu gibi aileler :

a- Cocuksuz veya az çocuklu olmalıdırlar. Aile içindeki mevcut çocuk sayısı ne kadar çok olursa ana babanın çocuklara

(15) Fazla bilgi için bk. AKINTƯRK, Turgut: a.g.e., sh. 273 vd. 
karșı ayrı ayrı gösterecekleri ilgi ve yetiștirme görevi de o derecede azalmaktadır. Bundan dolayı çocuk aile yanına verilirken bu hususa dikkat edilmelidir.

b - Aile (ana baba) orta yaşlanda bulunmalıdır. Her ne kadar bazı yazarlar karşı fikirde iseler de, yani çocuklarla yanlarına verilecekleri aileler arasında fazla yaș farkı bulunmaması geriektiğini ileri sürerlerse de (16) çocukla yanına verileceği şahıslar árasında belirli bir yaș farkının bulunması gereklidir. Bir kere arada belirli bir yaş farkı bulunmazsa normal ana baba çocuk ilişkilerini să̆. lamak zorlaşacaktır. Korunmaya muhtaç çocuklar hakkındaki korunma tedbirleri genellikle onsekiz yaşlarım doldurmalarına kadar devam eder (17). Yani herhangi bir çocuk onsekiz yaşını bitirene kadar bir aile tarafından bakılıp yetiștirilmesi için alınabilir. Eger arada az yaş farkı olsun dersek bu demektir ki; onyedi yaşındaki bir çocúk yirmi - yirmibeș yaşları arasındaki bir aile yanına verilebilecektir. Bu durumda bu çocukla kendisini yanına ălan şahıslar arasında acaba normal bir ana baba ilişsisi kurulabilecek midir? Zaannetmiyoruz. Çocuk aile fertlerini bir ana baba gibi değil, belki bir arkadaş gibi görecek ve davranışlarımı da ona göre ayarlayacaktır. Onun için belirli bir yaș farkı gereklidir. Aile fertleri orta yaşta, yani otuzbeş ile kırk yașları arasında olmalıdır.

$\mathrm{c}$ - Aile fertlerinin sağık durumu yerinde olmalıdır. Bu demektir ki; aile fertlerinin sağlıklarmı çocuğa zararı dokunacak durumda olmaması, ayrıca aile fertlerinin çocukla yeteri kadar ilgilenip yetiștirebilmeleri için sağlık yönünden bir engellerinin de bulummaması gerekir.

d- Aile fertleri iyi hal sahibi, dayanklı ve dengeli bir kişiliğe sahip olmalıdır. Gerek iş yerlerinde - eğer çalışıyorlarsa - ve gerekse oturdukları çevrelerde bu şekilde tanımalıdırlar. Aile hayatları düzenli ve iyi seviyede bulunmalıdır. Ahlâkî kişiliğge sahip kimse ler olmalidirlar.

e- Çocuğun yanına yerleştirilece ği ailenin, çocukları yetiştirme ve bakma işine istekli olmaları gerekir. Halbuki tatbikatta bu gibi şahıslara, birliklerce, yanlarına verilen çocukların masraflarını karşılamak üzere yıllık belirli bir ücret verilmektedir. Bu durumda aile fertleri çocuklara kendi istekleri ile bakan kişiler olmak-

(16) Bu hususta bk. DEMIRDAĞ, Bahtiyar: Kimsesiz çocuklar meselesi, Iller ve Belediyeler dergisi, 1953, S. 95, sh. 8 vd.

(17) Bu hususta bk. «Korunma süresi» sh. 217 vd. 
tan çıkıp, adeta para karşılığı bakan kişiler durumuna girmektedirler. Araya para kavramı girince ilișkiler de ona göre değişip maddîleşmektedir. Halbuki çocuklan kendilerine bakacak kişiler yanına değil de onları evlât edinecek kişiler yanına vermek bu yönden daha iyi sonuçlar doğuracaktır. Birlikler bu gibi çocukları evlât edinmek isteyen kimseleri tarayıp tespit edecek faaliyetleri göstermelidirler.

Bu çocukların yanlarına verildikleri ailelerin, çocuğun asıl ana babası olmadıklarının çocuk tarafından bilinmesinin acaba ne dereceye kadar önemi vardır? Gerçi çocukların bu gibi aileler yanına yerleştirilmelerindeki maksat onlardaki ana babadan yoksun olma. ları dolayısıyla mevcut olan hisleri yokedip onları gerçek bir aile yuvasına kavuşturmaktır. Fakat bu gibi çocukları yanlarına alan ailelerin, çocuğa onun asıl ana babası olmadıklarını fakat kendile. rinin de onun gibi bir çocuğa ihtiyaçları olduğunu, bundan böyle onun öz ana babası olacaklarmı ve onun da kendilerine karșı ayni hisleri beslemesi gerektiğini uygun bir şekilde anlatmalıdırlar (18).

2- Çocuğun bir müesseseye yerleştirilmesi :

Hâkim çocuk hakkındaki dosyayı inceler ve korunma tedbiri kararı verir. Bundan sonra çocuğun dosyasını ekli evrakla birlikte o bölggenin bağlı bulunduğu birliğe gönderir. Birlik, çocuğun özelliklerine ve elindeki imkânlara göre çocuğun bakılıp yetiștirilmesi için kendisine bağlı müesseselerden birisine yerleștirir. Bu müesseseler șu nitelikte olan müiesseselerdir :

a-- Normal eğitimi sağlayan müesseseler :

6972 sayılı Kanuna göre hakkında tedbir kararı alınan ve ayrıca herhangi bir özellik göstermeyen (19) çocuklar iki türlü müesseseden birisine yerleștirilebilirler (20). Bu müesseseler ya «mevcut hayır müesseseleri» yahut ta «6972 sayılı Kanun hükümlerine göre kurulan müesseseler» den biridir (KMÇHK m. 2).

Hayır müesseseleri çocukları koruma ve yetiştirme maksadı ile kurulmuş olan ve menfaat gayesi gütmeyen müesseselerdir.

(18) Demirağ, Bahtiyar: a.g.m., sh. 8.

(19) Özcllik gösteren çocukların eğitim ve bakımları özel eğitim müesseselerinde yapilır. Hangi çocuklarm özel eğitime muhtaç oldukları ve ve Özel eğitim müesseseleri daha sonra incelenecektir.

(20) Korunmaya Muhtaç Çocuklar Hakındaki Kanun m. 2/II 
Bunlar, ya hakiki şăhıslara (21) ya da bir tüzel kișiye ait olabilir (22). Çocuklar bu müesseselere yerleştirilirken, aileler yanına verilirken aranlan şartlar göz önünde tutulur (23).

Bu müesseseler çocuğun, meslekî fikrî ve bedenî yöndeki geliş. melerini sağlamak üzere gerekli işlemleri yapmak zorundadır. Bununla beraber çocukları bu müesseselere yerleştirilen birlikler de çocukla yakmdan ilgileneceklerdir. Devamlı olarak ve belirli zaman aralıkları ile çocukları gidip görecek ve durumlarını kontrol ede. ceklerdir.

6972 saylı Kanuna göre kurulan müesseseler ise, "Çocuk bakım yurtları» ve "Çocuk yetiştirme yurtları» olmak üzere iki türlüdür. Bunlardan çocuk bakım yurtları altı yaşına kadar olan çocuk. lar- altı yaş dahil- çocuk yetiştirme yurtları ise yedi ile onsekiz yaș arasındaki çocukları barındırmaktadır.

aa-- Çocuk bakım yurtları: Bu yurtlar altı yaşına kadar olan, yani henüz ögretim çağına gelmemiş çocuklar için aile ocağı vazifesi görmektedir. Bu yurtlar yatılıdır ve çocuklar burada altı yaşına kadar-altı yaş dahil - bakılıp yetiştirilirler. Bu yurtlarda çocuklar onbeș ile yirmi kișilik gruplar halinde ayrılır ve her grup büyük bir aile meydana getirecek şekilde küçük evlere veya pavyonlara yerleştirilir. Bu çocukların kişisel veya ortak ihtiyaçlarnı karşılamak ve onlarla yakından ilgilenmek üzere her gruba abla veya anne görevini yapacak ehliyetli kișiler verilir. Bunlara "Kümebaşı" denilir. Bu yurtlardaki çocuklar genel olarak özellik ve ihtiyaçlarına göre iki gruba ayrulırlar. 1- Doğumdan ikinci yaş sonuna kadar olan çocuklar, 2- Ǔçüncü yaş başından altıncı yaş sonuna kadạr olan çocuklar. Bu gruplar için ayrı ayrı müesseseler kurulabileceği gibi, ayni muiesesese içinde de bir araya toplanabilirler. Doğumdan ikinci yaş sonuna kadar olan çocukla rın barındıkları yurtlar Sağlık ve Sosyal Yardım Bakanlıł̆ının ha zırlayacă̆ proğrama göre, üçüncï yaș bașından altıncı yaş sonu na kadar olan çocukların barındıkları yurtlar ise Millî Eğitim Ba. kanlığının "Ana okulları yönetmeliği» gercğince yönetilir. Çocuğun barındırıldığı yer büyük bir merkezse ve burada ana okulu varsa üç

(21) Bu müesseselere örnek olmak üzere Hayri Ipar tarafindan Mudanyada, Nuh Naci Yazgan tarafindan Adanada açllan çocuk yuvalarmo örnek gösterebiliriz: Fakat bunlar devamlı olamamışlardır.

(22) Örneğin Çocuk Esirgeme Kurumu'na bağlı olarak halen Ankarada «Keçiören Çocuk Bakmm Yurdu» vardır.

(23) Bu hususta bk. sh. 189 vd. 
jle altı yaş arasındaki çocuklar bu ana okullarına gönderilirler. Bunlarm okul giderleri bağlı bulundukları birliklerce ödenir. Ana okullarına gönderilen çocuklar geceleri, pansiyon vazifesi gören bakım yurtlarinda kalırlar.

Bakım yurtlarında bakılmakta olan çocuklar altı yaşını doldurunca, yani ilk öğretim çağına gelince yetiştirme yurtlarına devrolunurlar.

Bakım yurtları Sağlık ve Sosyal Yardım Bakanlığının kontrol ve murakabesi altındadır (KMÇHK m. 6/II). Bu yurtlara adı geçen Bakanlık her türlï yardımda bulunmakla mükelleftir (KMÇHK m. 4/II).

Yeni açlacak bakim yurtlarının bina ve ilgili tesisleri Sağlık ve Sosyal Yardım Bakanlığı ile Bayındırlık Bakanlığının birlikte hazırlayacakları plânlara göre yapılır. Mevcut bakım yurtlarının yapılarının onarılması, yeniden düzenlenmesi ve değiştirilmesi ile ilgili planlar da Sağlık ve Sosyal Yardım Bakanlığı tarafindan yapilur.

Çocuk bakım yurtlarında bulunan çocukların sağlık durumları jle yakından ilgilenilir. Bu iş için gerekli doktor, sağlık memuru ve diğer personel Sağlık ve Sosyal Yardım Bakanlığı tarafından atanır (KMÇHK m. 7). Bunların dışında yurtların bulunduğu yerde yapılabilecek - Bakanlığın atamalan dıșındaki atamalar personel atanmaları ise yurdun bağlı bulunduğu birlik yönetim kurulunca yapılır. $\mathrm{Bu}$ atamalar birliğin genel kongresinde tayin olunur. Çocuk bakım yurtlarının memur ve müstahdemleri resmi memur ve müstahdemler sayılır ve belediye memurlarının hak ve vecibelerine sahip bulunurlar.

$\mathrm{Bu}$ yurtların giderlerini karşılamak üzere bakanlıkların yaptıkları yardımlardan başka, birliğin bağlı bulunduğu belediyeler ve İl özel idareleri de bütçelerine gerekli tahsisatı koymak zorundadırłar (24). Birlikleri kurmak için belediye ve özel idarelerin ayırdıkları tahsisatlar yeterli değilse, çevredeki diğer belediye ve özel idarelerle birlikte bu birlikleri kurarlar. Bu dahi mümkün değilse mevcut birliklerden birisine üye olarak girilir (KMÇHK m. 10).

Yukarıda belirtildiği gibi bu yurttlarda çocuklar en çok onbeşyirmi kişilik gruplara ayrılırlar. Bu, çocuklara mümkün olduğu ka-

(24) Bu hususta fazla bilgi için bk. Mali Kaynaklar bahsi sh. 230 vd, 
dar bir aile çevresinde oldukları hissini vermek içindir. Bu durumda mümkün olduğu kadar fazla sayıda bakım yurtları açmak gerekir. Fakat yeni bir bakım yurdunun açılması da çok masraflıdır ve onu açacak olan bir birliğin varlığına bağlıdır. KMÇHK nun 10 uncu maddesine göre belediye ve özel idarelerin tahsisatlan birlik kurmaya yetmeyince bunlar çevredeki belediye ve özel idareler. le birlikte bir birlik kurarlar. Bu dahi mümkün olmazsa mevcut birliklerden birisine üye olarak girerler. Birliklerin kurulup devam ettirilmesi masraflı olduğu için belediye ve özel idareler çevredeki birliklere ìye olarak girmekte ve onların tesislerinden faydalan. maktadirlar.

Halbuki her belediye ve özel idare bir birlik ve birlikler de korunmaya muhtaç çocuklar için gerekli yurt ve müiesseseleri aç. salardı o nispette çok sayıda korunmaya muhtaç çocuk kalabalık olmayan kümeler halinde barındırılabilecekti. Bugün birçok korun. maya muhtaç çocuk yurtlara girebilmek için sıra beklemektedir* ler. Bunu önliyebilmek için de yeni yurtların kurulmasını ve yurt sayısının artmasını önleyici nitelikte olan 6972 sayılı Kanunun 10 uncu maddesi, bu sakıncaları ortadan kaldıracak şekilde düzeltilmelidir. Bunun için de Sağlık ve Sosyal Yardım Bakanlığının bir. liklere yaptığı yardımlar çoğaltılmalı ve birliklerin yurt kurması için yapılan yardım fonu olarak ayrı bir fon meydana getirmelidir.

bb- Çocuk Yetiştirme Yurtları: Bu yurtlar, öretim çă̆ına gelmiş - yedi yaş başları ile onyedi yaş sonu arasındaki - çocukların bakım ve yetiştirilmeleri için kurulurlar. Bu yurtlar hiç bir zaman bir kışla, bir ıslah evi olarak değil, çocukların daha serbest ve daha samimi bir şekilde bir arada yaşayan bir topluluk meydana ge. tirmelerini sağlamak üzere kurulmuşlardır. Bu yurtlarda çocuklar yirmibeş ile otuzar kişilik gruplar halinde kümelenir ve her küme büyücek bir aile meydana getirecek şekilde evlere veya pavyonlara yerleștirilirler. Her kümeye ögretmen olan bir kümebaşı verilir Tercihan bu kümebaşları evli, bu ișlere istekli ve ehil olanlar arasından seçilir. Bu kümebaşları çocukların her türlü kişisel ve ortak ihtiyaçları ile ilgilenir. Yetiştirme yurtları gerek toplumla ve gerek. se toplum içindeki çeşitli müesseselerle ilişkiler kurabilmek için daha çok şehirler içinde kurulur. Ayni zamanda bu yerlerin toprak işleriyle ve yatılı okullarda uğrașlan diğer işlerle ugraşmaya elverișli bir yer olmasma da dikkat edilir.

Yetiştirme yurtları, bulundukları çevrenin yetenek ve özellikleri ile içinde bulunduracă̆ı çocukların değişik ve ortak özellikle- 
rine göre çeșitli şekillerde kurulabilir. Fakat bununla beraber her yetiștirme yurdunda intiyaca yetecek ölçüde şunlar bulunmalıdır: en azından bir revir, bir banyo, bir çamaşırlık, bir mutfak, bir anbar veya depo, bir kütüphane, yeteri kadar yatakhane, hela, çalıșma, eğlenme, dinlenme ve oyun yerleri ile memur ve hizmetlilerin lojmanları.

Yeni açlacak yetiştirme yurtlarının yapı ve ilgili kuruluşları, Milli Egitim ve Baymdırlık bakanliklarının ortaklaşa hazırlayacak. ları plânlara göre yapılır. Mevcut yurtların yapı ve kuruluşlarının değiștirilme, onarılma ve geniş̧letilme plânları da Milli Eğitim Ba. kanlığınca hazırlanır.

Büyük şehirlerde kurulan yetiştirme yurtları daha çok şehirlerden toplanan çocukların bakılıp yetiştirilmeleri için çaba harcarlar. Bu gibi yurtlarda kümeler beș ile on kişiden, yurdun toplam sayısı da 300 kişiden fazla olamaz. Bu yurtlar daha çok ilk ve orta okullar ile meslek okullarına ve işyerlerine yakın çevrelerde kurulur. Eğer mümkünse bu yurtlardaki çocuklarn ilk ögrenimleri ve gerekenler için meslek öğrenimleri şehirlerde sağlanır.

Oğretim yapılan okul ve kurs binaları dıșında, yetiştirme yurt. ları çocukların devamlı olarak kaldıkları bir merkez halindedir. Çocuklar burada kalır, derslerini hazırlar, kütüphanesinde okurlar, oyun, spor, temsil, gezi faaliyetlerinde bulunurlar, eğlenirler, bahçe ișleriyle utgraşırlar, dinlenirler, ferdî veya toplu olarak ders dışı bazı faaliyetlerde bulunurlar. Yurtların da bütün bu faaliyetlere uygun ve yeterli derecede kurulmaları gerektiği gibi, ilgili personelin de buna göre seçilmeleri gerekir.

Bir yerdeki korunmaya muhtaç çocuk sayısı çoksa ve burası büyük bir merkezse bu şehrin diğer semtlerinde de yeni yetiştirme yurtları açılması yoluna gidilir (25).

Bir yerde birden çok yetiştirme yurdu varsa bu takdirde, çocuklar çeşitli gruplara ayrılarak ayn ayrı yurtlara yerleștirilebilirler. Bu aymm yaş yönünden olabilir. Bu takdirde; yedi ile dokuz, dokuz ile on, on ile onüç, onüç ile ondört, ondört ile onsekiz yaşları arasındaki çocuklar diye ayrılır. Ayrm çocukların cinsiyeti yönünden de yapilabilir. Bu takdirde yurtlar; kızlar yurdu, erkekler yurdu, karma yurtlar olmak üzere ayrılır. Aymm çocukların öğ.

(25) Bilindj̧̧i gibi bir yurttaki toplam çocuk sayısı $300 \ddot{\mathfrak{a}}$ geçmemelidir. 
renim durumlarına göre de okur yazar olmayanlar, ilkokulu herhangi bir sunfından terkedenler, ilkokulu bitirenler veya bir dereceye kadar meslek eğitimi yahut ilkokul üstünde genel eğitim görmüş bulunanlar vs. olarak yapilabilir.

Şehir yakınlarında veya .şehirlerden uzaklarda kurulan yetiştirme yurtları, daha çok köylerden ve küicuik kasabalardan gelen ve süresi dolunca yine buralara dönmesi yararlı olan çocuklarla şehirlerden toplanıp ta șehirlerde kalmaları bedence, ruhça ve sosyal yönden sakıncalı görülen çocuklan barındırırlar. Yetenekleri tarımsal yönde gelişen çocuklar da bu gruba katılırlar. Bu yurtlar șehirlerdeki yetiştirme yurtları gibi kurulup işletilirler. Bu yurtların yakınlarında ilkokul, ortaokul ve diğer meslek okulları varsa çocukların öğretimleri buralarda sağlanır. Yakınlarında bu gibi ögretim kuruluşları bulunmayan yurtlarda çocukların ilk, orta ve meslek ögretimleri yurt içinde sağlanır. Bunun için de yaşları elverişli olan, yani henüz öğrenim çağı başında bulunan çocuklar için yurt içinde normal bir ilkokul açılır ve çocukların ilk öğrenimleri normal yolla sağlanır. Öğrenim yaşları ilerlemiş olan çocuklar için okullarda akşam dersleri ve yaz kursları ile mecburi öğrenim sağlanır.

Bu yurtlardaki çocukların meslek öğrenimleri, çevrenin önemli tarım, ticaret ve sanat faaliyetleri yönünde düzenlenecek, döner sermayeli okul atölyelerinde kısa devreli kurslar halinde sağlana. caktır. Küçük yerlerde kurulan yetiştirme müesseselerinde büyük yerlerde kurulanlarına kıyasla okul karakteri daha çok göze çar. par. Bunların kuruluş ve personeli de buna göre kurulur ve seçi. lir.

Bir ilde yalnız bir tip yetiştirme yurdu bulunursa ve bu yurtta yukarnda belirttiğ̈imiz ayrımlara göre başka tip yetiştirme yurduna gönderilmesi gereken çocuk bulunursa, çocuğun bağlı bulun. duğu birlik yurtlarla anlașarak her türlü harcamalarını ödemek şartıyla bu gibi çocukları kendilerine uygun gelen tipteki yurtlara nakledebilir.

Haklarında korunma kararı alınp ta yurtlara daimi olarak yerleştirilmeye gönderilen çocuklarla, hakkında korunma kararı alınması için mahkemeye başvurulup ta durumu acil olduğu için geçici olarak yerleştirilmeye gönderilen çocuklar tanıma ve deneme maksadıyla diğer çocuklardan ayrı bir ev veya pavyona yerleştiri. lirler. Tanıma ve deneme devresi dört ile sekiz hafta sürer. Bu dev. 
rede bu çocukların çevrelerine intibak etmelerini sağlayacak her türlii tedbirler alındığı gibi her çocuğun tek tek sağlık, psikolojik, sosyal ve aklî durumlanı ile yakından ilgilenerek tanınmaya ve özel problemleri keșfedilmeye çalışılır.

Daha önce çocuk bakım yurdunda bulunup ta oradaki süresi dolmuş ve yetiştirme yurduna teslim edilmiş olan çocukların tant. ma ve deneme işi yetkili bir komite tarafından yapılır.

Tanıma ve deneme işlerinde çalışacaklarda aranan nitelikleri, bu işte uygulanacak metodu, testleri ve test dışı diğer objektif malzemeleri (26) Milli Eğitim Bakanlı̆̆ı tespit eder ve sağlar. Bu va. sitaların kullanılması ve olay ve inceleme, kişisel ve gruplar halindeki mülakat metodlarımı açklayan rehberleri de Milli Eğitim Ba. kanlığı hazırlar.

Bir yerde birden fazla yetiştirme yurdu varsa, daha esasilı ve sürekli tanıma ve deneme, tedbir alma maksadıyla ortaklaşa «Deneme ve Ayırma İstasyonları" ile "Psikoloji merkezleri» kurulur. Bu istasyon ve merkezler komşu illerde ortaklașa da kurulabilir. Deneme ve tanıma istasyonlarmda çocuklar, yaş, cinsiyet veya öğrenim durumlarına göre sinflandırlırlar ve tanıma devresinde müesseselere ayak uydurmalarını sağlıyacak ve kendilerinin tanınmalarına yarayacak türlü ders dışı çalıșmalara yöneltilir. Deneme ve tanıtma yurtları da büyük șehirlerdeki yetiștirme yurtları gibi düzenlenir ve işletilebilirler.

Deneme ve tanıma devresi sonunda her çocuk için açılan dosya tamamlarır ve elde edilen sonuçlara göre çocuk kendisine en uygun gelen kümeye veya müesseseye usulüne göre yerleștirilir.

Yetiștirme yurtları Milli Eğitim Bakanlığının denetimi altındadır. (KMÇHK m. 6). Bu yurtlara Milli Eğjtim Bakanlığı her türlü yardımda bulunmakla yükümlüdür (KMÇHK $\mathrm{m}$. 4/II). Yetiștirme yurdunu belirli bir bölgedeki birlik kurar, eğer o bölgede yetiștirme yurdu kurmak mümkün olmazsa Milli Eğitim, Sağllk ve Sos. yal Yardım ve Iç̧ş̧leri bakanlıklarının tayin edecekleri çevrelerde. ki yurt ortaklaşa kurulu. Yetiștirme yurtlarındaki çocukların sağ. lık durumları ile ilgilenecek personel, Sağlık ve Sosyal Yardım Bakanlığı tarafından atanır. Bu iş için atanan doktor ve sağllk hizmetlileri yurtlardaki çocukları sıkı bir są̆lık kontrolu altında bulundururlar. Bu yurtlarda bakklıp yetiştirilen çocukların bir mes.

(26) Bundan maksat genel öłretim müesseselerinde kullanılan araçlardır. 
lek ve sanat sahibi edilmeleri de göz önünde tutulur. Bu iş için gerekli öłretmen ve teknik eleman Milli Eğitim Bakanlığınca sağ. lanır (KMÇHK m. ). Bu yurtların memur ve hizmetlileri de resmi sıfaitı ve Belediye memurların hak ve vazifelerini haizdirler.

6972 sayll Kanunun yedinci maddesinde belirtildiği gibi, yetiştirme yurtlarındaki çocukların ilk ögrenimleri zorunlu olarak sağlanır. İlk ögrenimden sonra kabiliyetli olan çocuklara daha ileri seviyede ögrenim fursatı sağlanır (KMÇHK m. 15). Bu gibi çocukların ögrretim şartları Milli Eğitim Bakanlı̆̆ı tarafından tesbit edilir. Ögrrenim imkânt sağlanan çocuklar, her derecedeki genel öğrenim kuruluşları ile, meslek okul ve kuruluşlarma yerleştirilir. ler. Öğrenimin yanısıra, ilk öğrenimden sonra kabiliyeti olmayan ve ileri seviyede öğrenime devam edemeyen çocuklar ise bir meslek ve sanat sahibi edilmek üzere gerekli atölye ve işyerine veya mes. lek okullarına yerleștirilirler. Çocukların öğrenimi iki yolla sağlanabilir.

aa - Yetiștirme yurtları dışında : Yetiştirme yurtları șehirlerde kurulacak ise bunlar için ilk ve orta ögrenim kuruluşları ile meslek okullarınır bulunduğu çevreler tercih edilir. Bu takdirde çocuklar öğrenimlerini bu müesseselerde görürler. Yurt binası dişındaki genel okul ve kuruluşlarda öğrenim gören çocukların ögrenim giderleri, bağlı bulundukları birliklerce sağlanır. Dışarıda ögrenim gören çocuklarmn yurtları, onların barımma merkezleri görevini görür. Ilk ögrenimden sonra kabiliyetli olan çocuklar ileri seviyede ögre. nime devam ettirilirler. Bunlar kabiliyetlerine, ögrenime karşı olan ilgilerine ve yaşlarına göre Milli Eğitim bakanhı̆ının tayin ve tes. bit edeceği șartlar altında yatılı, yatısız her derecedeki genel öğretim kuruluşları ile meslek öğrenimi veren kuruluşlara yerleştirilirler. Bağlı bulundukları yurtlar bu çocukları öğrenimleri sırasın. da yakından denetler ve onlarla ilgilenir.

Ilk öğrenimlerini bitirdikten sonra yatılı veya yatısız olarak ileri seviyedeki öğrenime devam etmeleri uygun olmayan veya ilk öğrenim görmeden öğrenim çağını doldurmuş bulunan çocukların kısa yoldan iş ve meslek sahibi yapılmaları sağlanır. Bunun için çocuklar genel ve katma bütçeli daireler, özel idareler, belediyeler. 3659 sayıl kanuna bağh kuruluşlar ve sermayesinin yarısından fazlası devlete ait olan diğer kuruluşlar tarafından kurulmuş fab. rika, diğer her türlü tesis ve tarım işletmelerinde çalıştırılmak suretiyle iş sahibi edilirler. Bu gibi çocukların bakım ve yerleștirilmeleri ile ilgili harcamalar yerleştirildikleri kuruluşlar tarafundan 
karșlanır (KMÇHK m. 16). Bu kuruluşların çocuğun masrafları. nı karşıllamaları mümkün değilse çocuğun bağlı bulunduğu yetiş. tirme yurdu bu masrafları karşılayacaktır (KMÇHK m. 17).

Böyle bir müesseseye yerleștirilemeyen çocuklar, özel fabrika ve işyerlerine çırakhk yapmak üzere yerleștirilerek iş sahibi edile. bilirler. Çocuğun bu gibi yerlere yerleștirilirken onun bakım ve yetişme masraflarını üstlerine alanlar tercih edilirler (KMÇHK m. 16). Eğer çocuğun bakım masraflarını karşılayacak bir müessese bulunmazsa, bu giderler çocuğun bağlı bulunduğu yurtlar tarafın. dan karșılanır (KMÇHK m. 17).

İs ve meslek sahibi edilmek üzere bir yere yerleștirilen çocuk. larn durumları, yurt idarecileri ile işyeri sahipleri veya yetkili ki. şiler arasında bir yazılı sözleşme ile kararlaștrrılır. Çocuklar bu yerlere bir çrraklık sözleșmesi veya ücretli bir sözleșme ile bağlı bulunabilirler. Köylerde veya çiftçiler yanında çalıșan çocuklar ay. nî bir ücret alabilirler. Ücretin bașlama zamanı, süresi ve miktarı işveren ile yurt idarecileri arasında tesbit edilir. Ücretle bir yerde çalıșan çocuklarm aldıkları ücretten birlik encümenince tayin edi. lecek belirli bir kısmı, çocuğun bakılma ve yetiștirilmesine katılma payı olarak ayrılır, bunun dıșında yine birlik encümenince tayin edilen çocuğun belli miktardaki harçhı̆̆ da ayrıldıktan sonra geri kalanı çocuk adına millî bankalardan birinde açtırılacak hesaba yatırılır (KMÇঙIK m. 18). Çocuk aynî ücret karşılı̆̆ı çalışmışsa bunlardan paraya çevrilmesi kabil olanlar paraya çevrilerek çocuk adı. na bankada açtırılacak hesaba yatırıłr. Paraya çevrilemiyenler köy ihtiyar kurulunca değerlendirilerek çocuk adına saklanır.

Çocuklar reșit olunca bankada onlar adına saklanan paralar kendilerine verilir. Bu çocuklar hakkında Medenî Kanunun 398 inci maddesi geçerli değildir (KMÇHK m. 20). Medenì Kanunun adı geçen maddesinde vesayet altındaki şahsın, kendi tasarrufuna bıra. kılan mallarla vasisinin izni ile çalıșarak kazandığı malları bizzat kendisinin idare edebileceği belirtilmektedir. Bu çocukların banka. daki paraları yurt ilgililerinin izni ve imzası olmadan çekilemez.

bb - Yetiștirme yurtları içinde : Yetiştirme yurtlarının yakınlarında ilkokul, ortaokul ve diğer meslek okulları varsa, yukarıda belirtildiğ gibi çocuklarm öğrenimleri, giderleri yurtlar tarafından karşılanmak üzere buralarda sağlanır. Fakat yurtların yakınında bu șekilde öğrenim kuruluşları yoksa, çocukların ilk, orta ve meslek öğrenimlerini sağlamak üzere yurtlar içinde birtakım tedbirler 
alınır. Bu tedbirlerden olmak üzere okullar ve kurslar açılır. Henüz öğrenim çağında bulunan çocuklar için yurt içinde ilkokullar açılır ve çocukların ilk ögrenimleri genel metodlarla sağlanır. Öğrenim yaşı ilerlemiş olan çocuklar için ise yurtlarda akşam dersleri ve yaz kursları açılarak bunların ilk öğrenimleri de mecburi yolla sağlanır. Bu sekilde ilk ögrenimlerini tamamlayan ve ileri seviyede ögrenime devam edebilecek kabiliyette olan çocuklara daha önce anlatıldığı gibi ileri seviyede ögrenim yapma imkânlan sağlanır (27).

Daha ileri seviyede öğrenim yapma kabiliyetleri olmayan çocukların kısa ve çabuk yoldan bir meslek ve sanat sahibi olmalarını sağlamak için bunlar yurtların çevrelerindeki meslek ve sanat okulları ile atölye ve işyerlerine yerleştirilirler. Fakat yurtların çevresinde böyle yerler yoksa yurtlar içinde bu yolda tedbirler alınır. Bunun için de o çevrenin ekonomik ihtiyaçları ile meslek sahibi edilmek istenen çocukların özellikleri göz önïnde tutularak döner sermaye ile işleyen çeşitli ve kısa süreli ticaret ve ziraat kursları açllır.

Yetiştirme yurtlarında açılacak atölyelerin programları çevrenin meslek ögretmenleri ile ilgililerden meydana gelecek bir komisyon tarafından hazırlanır ve Milli Eğitim Bakanlığının onayına sutnulur. Yetiştirme yurtlarında ne gibi atölyelerin açlacağına yurdun ögretmenler kurulu karar verir.

Gerek yurtlar içinde ve gerekse yurtlar dışında iş ve meslek alanında yetiştirilmek üzere atölyelere yerleştirilen çocuklarda as"lolan o iș ve meslekle ilgili hüner ve maharetlerin kazanılmasıdır. Atölyelerin çalışma programları da buna göre düzenlenir. Çocuk. ların işyerleri, atölye ve meslek sahibi olmak için yerleștirildikleri yerlerdeki durumları da yakından denetlenir. Çocukların sağlık ve eğitim durumlarında bir aksama görülürse, çocuğu barındıran ve. ya yetiștiren kiși veya müesseseye önce bir ihtarda bulunulur. Buna rağmen durum düzelmezse bu gibi kişi ve kuruluşların çocuk yetiștirmeleri yasaklanır ve yerine göre kuruluşlar kapatılır (KMÇHK m. 23).

Yetiştirme yurtlarında bulunan çocuklar yurtlardan kaçacak olurlarsa zabıtanın yardımiyla bulunularak geri getirilirler. Yurtlardan ikinci defa kaçan çocuklar hakkında ne gibi tedbirlerin alınacağı hakkında herhangi bir hüküm yoktur. Bu gibi çocukların

(27) Bu hususta bk. sh. 197. 
"çalıșma metodu ile islah» esasına dayanan çocuk islah evlerine yerleştirilmeleri gerekir (28).

Bir kuruluș veya ișyerine yerleștirilen çocukların yerleri bağl. bulundukları birliklerin izni olmadan değiștirilemez. Ve çocuklar buraları terekedemezler (KMÇHK m. 24). Çocuklar buraları gizlice terkederlerse özel işyeri veya kuruluşların sahip ve sorumluları durumu hemen ilgili yetiştirme yurduna bildirirler.

Ozel işyerleri veya kuruluşlara yerleştirilen çocuklara karș1 Türk Ceza Kanununun 429 ve sonraki maddelerindeki suçları işleyen kimseler bir seneye kadar hapis cezası ile mahkûm edilirler (29).

İşyerlerinde veya özel şahıslar yanında çalışan çoctukların paralarını gerekli müddeti içinde birliğine veya bankalara yatırmayan ve çocuk reşit olduktan sonra bankalardan alınan paraları çocuğa geri vermeyenler hakkinda 3 ay ile bir sene arasinda hapis 200 ile 2000 lira arasında hafif para cezası tatbik olunur (KMÇHK m. 26). Çocuklara aynî ücret olarak verilen malları, korumayan ve saklamayanlar hakkında 200 ile 2000 lira arasında ağır para cezası uygulanır (KMÇHK m. 26/III).

b- Olağanüstü hallerde bahis konusu olan müesseseler :

Bunlar beden, zihin ve sosyal özürleri veya özellikleri dolayl. sıyla bakım ve yetiştirme yurtlarının normal programları içinde yetiștirilmelerine imkân olmayan ve özel eğitimi gerektiren çocukJar için açılan yurtlardır. Bu yurtlar da başlıca iki tiptir.

aa-- Beden ve zihin yaplları özürlü olan veya özellik gösteren çocuklar için açılan yurtlar :

Bu yurtlar sffır ile onsekiz yas arasında bulunan ve beden ve zihin yapılş̦ları önemli derecede özürlü olan veya özellik gösteren çocuklar için açlır. Bu yurtları Millî Éğitim Bakanlığı kurar, ayni zamanda bu çocuklar için kurulan özel yurtlardan başka bu maksatla açılmıs resmi ve özel kuruluşlardan da faydalanılır. Beden ve zihin yapılıșları özürlì olan veya özellik gösteren çocuklar da bașlica alt 1 gruba ayrilırlar :

(28) Bu hususta bk. ZEVKLILER, Aydın: Çocuk Suçluluğu (Seminer ödcvi) Ankara Hukuk Fakültesi, 1964, sh. 26 vd.

(29) Fazla bilgi için bk. EREM, Faruk: Türk Ceza Hukuku, Özel HükümJer, Íkinci bask1, Ankara 1965, sh. 773 vd, 
1 - Körler ve iyi görmeyenler

2 - Sağırlar ve iyi duymayanlar

3 - Adale, kemik ve hareket sisteminde özrü olan sakatlar

4 - Ustün zekalılar ve istidatlılar

5 - Geri zekalılar

6 - Eğitimi zor çocuklar

Bazı çocukların birden çok özrü olabilir. Bu takdirde hakim vasıftaki özrünü ilgilendiren yurtlara yerleştirilirler. Milli Eğitim Bakanlığı bu gibi çocuklar için yatılı okul ve sımıflar seklinde kuruluşlar açar. Bu kuruluşlar; ana okulları, ilkokullar, orta dereceli geneI ögrenim veren okullar, meslek okul ve kursları seklinde ola. bilir. Bu kuruluşlar ayrı ayrı yerlerde açılabilecekleri gibi, hepsi veya birkaçı bir arada açllabilir. Bir yerde bu gibi özellik arzeden çocuklar çok sayıda ise, sınıflar açma yoluna gidilir. Bu gibi yurtlar daha çok şehir kıyılarında, sosyal çevre ve kuruluşlarla kolayca ilişkiler kurulabilecek yerler ile toprak, tarım işlerine elverişli olan yerlerde kurulurlar. Bir yerdeki özel öğrenim kuruluşları birden fazla ise burada deneme ve tanmma istasyonları ile çocuklarn iyileșmelerini sağlayacak psikolojik merkez ve klinikler de açılır.

Özel eğitimi gerektiren çocuklar için açılan yurtlara, gerekirse korunmaya muhtaç olmayan fakat özürlü. bulunan çocuklar da gündüzlü veya yatılı olarak yerleștirịlebilirler. Yatılı olarak devam edecek olan bu gibi çocuklardan eğitilmeleri karşıltğında belirli bir ücret alınır. Bu ücretin miktarı il veya ilçe yönetim kurullarınca tespit edilir. Bu yaplırken yurda devam edecek çocuğun maddì durumu ve bir yıllık masrafları esas tutulur.

Korunmaya muhtaç çocukların bakım masraflarını nüfusa kayıtlı oldukları yerdeki çocuk koruma birlikleri öder.

Özel eğitime muhtaç çocukların ögrenimlerinin kolayca sağlanabilmesi için bunlar mümkün olduğu kadar erken - okul çağından once - aranıp bulunmalidirlar. rilir :

Özel eğitim müesseselerinin faaliyetleri başlıca şu gruplara ay-

1 - Tanima ve tedavi

2 - Hazırlık ve intibak smifları

3 - Ilk ögrenimi mecburi olarak tamamlama

4 - Çocuklara meslek seçme ve kazandırma

5 - Ișe yerleştirilme ve takip. 
Bu kuruluşların özellikleri göz önünde tutularak imkân nispe. tinde bu kuruluşlara, ihtiyaca göre göz ve kulak doktorlar, okul psikoloğu, çocuk psikiyatristi, sosyal yardımcı, genel bulgu araçları ile iyileștirme araçları verilir.

Hazırlık ve intibak sınıflarında çocukların özürlerinin giderilmesine veya özürlerinden doğan bir kısım sonuçların hafifletilmesine çalışlır. Bundan maksat çocuğu normal ilk öğretime hazırlamaktır.

Özel eğitim kuruluşlarında diğer normal kuruluşlara nazaran toplu halde degil de ferdi bakım ve yetiştirme esastır. Yetiștirme faaliyetleri dışında diğer normal yurtlara benzeyen bir yol izlenir.

bb- Sosyal yönden özürlï olan çocuklar için açılan yurtlar :

Türk Ceza Kanununun 53, 54, 57 ve 58 inci maddelerine göre; haklarında eğitim tedbirleri alınması gereken çocuklar için Adalet Bakanlığı gerekli özel eğitim yurtlarını açar (30). Bu yurtlarm kurulması ve işletilmesinde Adalet Bakanlığı, Milli Eğitim ve Sağlık ve Sosyal Yardım Bakanlıkları ile sıkı işbirlił̧i yapar. Bu yurtların bina ve kurulușlarnnın plânları ile eğitim, program ve yönetmelik. leri her üç bakanlık tarafından ortaklaşa hazırlanır. Bu yurtlar esas itibariyle yetiştirme yurtları ile özel ögretim kuruluşlarının temel ilkelerine göre kurulur ve ișletilir. Bu yurtlara, Adalet, Millî Eğitim ve Sağlık şe Sosyal Yardım bakanlılıkları gerekli yardımlar. da bulunur ve yurtlarla yakından ilgilenip onlar denetler.

\section{B-OÖZEL TEDBİRLER :}

Bu tedbirler Medenî Kanun ve 6972 saylı Kanunda ortaklașa olarak değil de sadece birisinde, yani ya Medenî Kanun ya da 6972 sayılı Kanunda öngörülen tedbirlerdir. Bu tedbirler incelenirken yeri geldikçe, hangisinin hangi kanunda düzenlendiği de belirtilecektir.

$1 \sim$ Çocuğun bir şahıs yanına yerleștirilmesi :

Bu tedbir sadece 6972 sayılı Kanunda öngörülmüsştür. Hakkında korunma kararı verilmesi istenen çocuğun dosyasını inceleyen hâkim, eğer çocuğun yararına ise -çocuğun gruplar halinde diğer

(30) Fazla bilgi için bk. EREM, Faruk: Türk Ceza Hukuku, Genel Hükümler, C. I, ikinci bası, Ankara 1966, sh. 416.421. 
çocuklarla birlikte eğitiminin sakıncalı olması hali bir misaldir onun bir şahıs yanına yerleştirilmesi yolunda karar verir. Bu hal çocuğun bir şahıs tarafından evlât edinilmesi halinden başkadır. Burada şahıs, çocuğu evlât edinmemekte fakat, çocuğun bakım ve eğitimi sağlanmak üzere bu şahsın yanına yerleștirilmektedir. Çocukların giderlerini karşılamak üzere bağlı bulundukları birliklerce bu șahıslara belirli bir ücret verilir. Bu ücretler ytllık tutarla$\mathrm{n}_{1}$ üzerinden hesaplanarak verilir. Çocukların yanlarına yerkş̧irileceği kişiler, bunu yapmaya istekli ve ehil olmalıdırlar. Çocuk bir şahıs yanına yerleştirilirken çocuğun bağlı bulunduğu birlikle bu şahıs arasında yazılı bir sözleşme yapılır ve bu sözleșmede çocuğun bakım ve yetiștirilme şartları kararlaştırlır. Çocuğun yanına yerleștirildiği şahıs, çocukların meslek eğitimlerini ve genel öğrenimlerini sağlamak zorundadır. Bu kişi çocuğa, öz ana veya babası gibi muamele edecek, çocuğa ana babadan yoksun olduğunu unutturacak ve onu topluma yararlı bir kişi olarak yetiştirecektir. Gerek çoctukların bedenî, fikrî ve meslek eğitimlerinin ihmal edilmesini önlemek ve gerekse çocuğun bu kişi tarafından istismar edilmesine mani olmak için birlikler, çocuğun durumunu yakından ve sık sık denetlerler.

\section{2 - Ana babadan velâyetin nez'i :}

Bu tedbir sadece Medenî Kanunun «Hâkimin müdahalesi (m. 272)», «Himaye tedbirleri (m. 273)", "Çocukların yetiştirilmesi (m. 274)» başlıkları altında yer alan hükümlerinde öngörülmüștür. Medenî Kanun hükümleri gereğince çocuklar reşit oluncaya kadar ana babalarının velâyéti altındadırlar. Velâyet müessesesinin kapsamı çok geniştir. Veli sıfatımı taşyan ana baba çocuğun hem meslekî (MK m. 265) hem dinî (MK m. 266) eğitimi, hem de onun diğer bütün yönlerden eğitim ve yetiștirilmesi ife mükelleftirler. (MK m. 267). Velâyet görevini yerine getiren ana babanın bir çok mükellelefiyetleri yanında bir çok hakları da vardır. Ana baba çocuŏun her yönden yetişmesi ile yakından ilgilenecek ve gerekli titizliłgi gösterecektir. Ayrıca ana baba kanunî temsilci sıfatı ile çocuk adına her türlïi hukukî muameleyi yapacaktır. Ayrıca çocŭ̆un şahsî malları varsa onları da idare edeceklerdir. Özet olarak ana baba çocuğun malları ve şahsı üzerinde bir takım hak ve müikellefiyetlere sahiptir (31).

(31) Fazla bilgi için bk. VELIDEDEOĞLU, H. V. : a.g.e., sh. 348 vd., AKINTÜRK. Turgut : a.g.e., sh. 298 vd. 
Yukarıda sayılan bu mükellefiyet ve haklar ana baba- çocuk ilișkilerinin gerektirdiği normal sonuçlardır. Eğer bu sonuçlar sağlanamıyorsa, yani ana baba çocuğa karşı olan mükellefiyetlerini yerine getirmekte ve hakların kullanmakta gerektiği gibi titiz davranmıyor veya davranamiyorsa bu durumda ana baba- çocuk ilişkilerinde bir düzensizlik vardır. Bu düzensiz durumun ortadan kaldırılması için gerekli tedbirleri almak, hukuka, yani dolayısıyla topluma düşer. Ana babanın çocuk üzerindeki haklarını kötüye kullanmaları ve mükellefiyetlerini yerine getirmemeleri, toplumun iyilik duygularına, hukukun temel prensiplerinden birisi olan objektif hüsnüniyet kaidelerine ve bilhassa Medenî Kanun 288 e ay. kırı düșer.

Çocuk ilk bakışta aile içindeki durumu ile değerlendirilir. Fa. kat çocuk aslında sonunda toplumun malıdır, toplumun bir üyesi olarak ona katılmaktadır. Kiși, insan olarak daima egoist davranmak eğilimindedir. Ana baba-çocuk menafatleri çatıștı̆̆ı zaman aslolan daima ana babanın fedekârlıkta bulunmasıdır. Fakat öyle haller olabilir ki ana baba bencil duygularn etkisiyle çocuğun menfaatlerini ikinci plâna atıp kendilerininkini birinci plâna çıkarabilirler. Yahut ta ana baba çocuğuna karşı son derece kayıtsız davranabilir. Bu durumda ana baba hakkını açıkça kötüye kullanmasa dahi kendisine düșen görevleri yerine getirmemekte ve böylece çocuğun menfaatlerini yeteri kadar korumamaktadır. Bu yönden incelenince velâyetin nez'i müessesesinin önemi kolaylıkla anlaşılabilir. Bu sebepledir ki Medenî Kanunumuz velâyetin nez'i müessese. sini etraflı bir şekilde düzenlemiştir (MK m. 273 vd.) (32).

Medenî Kanun velâyetin nez'ini gerektiren halleri 274 üncü maddesinde iki șlk halinde düzenler. Bunlar velâyetin gerektił̣̌̆ gibi ifa edilmemesi hali ile ana babanın yeniden evlenmesi halleridir.

Korunmaya muhtaç çocuklar hakkındaki kanun açısından daha önemli olanı, velâyetin gereği gibi ifa edilmemesi halidir.

a- Velâyetin gereği gibi ifa edilmemesi :

Yukarıda, genel olarak, ana babanın çocuk üzerinde veli sıfatıyla bir takım haklara ve mükellefiyetlere sahip olduklarını gör. müştük. Ana baba bu mükellefiyetlerini yerine getirmez ya da geti. remezse Medenî Kanun gereğince velâyetin kendilerinden nez'i ge. rekir. Velâyetin nez'ini gerektiren haller nelerdir?

(32) Fazla bilgi için bk. VELIDEDEOGLU, H. V.: a.g.e., sh. 348 vd., AKIN. TUtRK, Turgut : a.g.e. sh. 298 vd. 
aa- Velinin nüfuzunu ağır surette suiistimal etmesi :

Ana babanın veli olmak sıfatıyla çocuğun şahsı ve mallan üzerinde bir takım hakları ve ödevleri vardır ( $\mathrm{MK} \mathrm{m}$. 262). Bunlar içinde en önemlileri : Çocuklara gerekli terbiyeyi vermek (MK. m. 264/I, II), Çocuğun mesleki terbiyesini yönetmek (MK m. 265), Çocuğa dinî terbiye vermek (MK m. 266/I), Çocuğu tedip etmek (MK. m. 267), Çocuğu, hukukî işlemlerinde temsil temek (MK. m. 268/I, II) dir (33).

Ana baba yukarıda sayılan hakları kullanırken ya da mükel. lefiyetleri yerine getirirken bunların sımırlarını aşabilir. Örneğin, çocuğa gerekli terbiyeyi verip onu tedip ederken, aşırı davranarak ona bedenen eza ve cefa edebilirler. Bu haller çocukta bedenî yönden bir takım gelişme gerilikleri veya özürleri meydana getirebileceği gibi manevî yönden de çocukta bir çöküntii yaratabilir.

Ayrıca ana baba çocuğun mallarını yönetirken veya çocuğu üçüncü şahıslara karşı temsil ederken kötü niyetle davranabilir ve böylelikle çocuğun parayla ölçülebilen menfaatleri zarara uğrayabilir.

Bu halleri önlemek için hâkim gerekli tedbirleri alır ve bu arada velâyeti de nez'edebilir (MK. 274/1) (34).

bb- Ana babanın velâyeti ifada fahiş ihmalde bulunması :

Ana baba velâyet müessesesinin icabı çocuk ile yakından ilgilenecek, çocuğun gerek şahsî ve gerekse mamelekî her türlü sorunlarına bir çözüm yolu bulmaya çalışacaktır. Bunu yapabilmek için de kendilerine Medenî Kanunla tanınan hakları kullanmak ve gereğinde yine bu kanunla yükletilen mükellefiyetleri yerine getirmek durumunda kalacaktır. Büitün bunları yaparken Medenî Kanun 2 nci maddesi, yani Objektif hüsnüniyet hükümlerine uygun hareket etmesi gerekir. Objektif hüsnïniyet kaidesinin bilhassa velâyet hakkından doğan hakların kullanılmasında ve borçların ifasında çok önemli bir fonksiyonu vardır.

Ana baba, velâyetten doğan haklarını dikkat ve titizlikle çocuğun yararna olacak șekilde kullanmalıdırlar.

Ana baba, çocuğun şahsı ve malları ile ilgilenmez, çocuğuna karşı devamlı kayıtsız davranırsa, kendisine Medenî Kanun 264/II

(33) Fazla bilgi çiin bk. AKINTÜRK, Turgut : a.g.e. sh. $284 \mathrm{vd.}$

(34) Fazla bilgi için bk. VELIDEDEOGLU, H. V.: a.g.e. sh. 452 vd. 
ve sonraki hükümlerle yükletilen mükellefiyetleri yerine getirmiyor demektir. Ana babanın çocuklarına karşı olan mükellefiyetlerini kasden yerine getirmedikleri haller bulunabileceği gibi, bunları ihmal de edebilirler. Fakat önemli olan çocuğun durumudur. Çocuk bu yüzden onarılması mümkün olmayan aksaklıklara sahip olabilir ve içinden kolayca kurtulamyyacağı kötü durumlarla başbaşa kalabilir. Örneğin, ana babasınm hiç ilgilenmeyip, başıboş bıraktı̆̆ı çocuğun uyuşturucu maddeleri kullanma alıșkanhğgna tutulması, başıbos serseri bir hayat yaşamaya başlaması, kötü kişilerle düşüp kalkması gibi. Mükellefiyetlerini bu șekilde ihmal eden ana babadan velâyetin nez'i hem Medenî Kanun 274/I ve hem de bu çocuğun menfaatleri icabıdır. Çünkü bu durumda Medenî Kanun 274/I in aradığı anlamda ana babanın "fahiş ihmali» bahis konusudur.

cc- Ana babanın velâyeti ifadan aciz olmaları :

Burada ana babanın kasdi, veya ağır ihmali söz konusu değildir. Ana baba velâyetten dogan mükelefiyetlerini yerine getirmeyi istemektedir, yerine getirdikleri kanısyyla da hareket etmektedirler. Fakat bu husustaki kabiliyetsizlikleri ya da davranışları dolayısıy. la başanılı olamamaktadırlar. Örneğin ana baba çok yaşıdır ve çocukla ilgilenecek güce sahip değillerđir. Bu yüzden çocukları ile gerektiği gibi meşgul olamamaktadırlar. Yahut ta ana baba yoksuldur ve ekonomik yetersizlikler yüzünden çocuğuna karşı yerine getirmekle yükümlü olduğu bakım mükellefiyetinin bir kısmını yerine getirememektedirler.

Bazen de ana baba cocuğuna karșı olan ödevlerini yerine getirmek için çaba harcar fakat bilgisiz, tecrübesiz olduğu için çocuğun mefaatlerine uygun olarak hareket edemez. Örneğin, çocuğu gerektiği gibi yetiştiremez. Ya da gerekli eğitim yollarını seçmede hataya düş̧üğü için çocuğun eğitimini gerektiği gibi sağłayamaz.

Bundan başka olarak ana babanın çocuğuna karşı olan mükellefiyetlerinden bazısını yerine getirmesi ve bazısının da velâyeti ifa hususundaki imkânsızlı̆g, kabiliyetsizliği, bilgi ve tecrübiyetsizliğgi görgüsüzlügü dolayısıyla istemiyerek veya bilmeyerek ihmal etmesi mümküudür.

Topluca incelediğimiz bu haller ana babanın velâyeti ifadan aciz olmalarn sonucunu doğurur ve gerekirse ana babadan velâyetin nez'ini gerektirir (MK. m. 274/I).

dd- Ana babanin mahcur olması:

Medenî Kanunumuz hacir altma alınmayı gerektiren sebepleri velâyetle ilgili hükümleri içersinde düzenlemiş̧tir. Medenî Kanun 
355 gereğince; «Akıl hastahı̆ı veya akıl zayıflı̆̆ı, israf, ayyaşhk, suihal ve suiidare ve bir sene ve daha fazla hürriyeti bağlayncı cezalara çarptırılmış olmak» halleri birer hacir sebebi teşkil eder. Hacir altına alınan kișinin fiil ehliyeti tam değildir, hatta bazı hallerde bu ehliyeti hiç yoktur. Şahıs tam ehliyetsiz durumdadır. Bunlar çoğu zaman kendilerini idareden ve kendi işlerini gereği gibi görmekten acizdirler. Bunları kanunen temsil etmek üzere bir vasi tayin edilir (35).

Kendileri kendi işlerini görmekten aciz olan ana baba çocuklarına karşı olan ödevlerini yerine getiremiyeceklerdir. Işte buna dayanarak Medenî Kanun bu gibi hallerde onlardan velâyetin nez'ini öngörmüiştür (MK m. 274/I) (36).

Burada genel olarak șunu belirtmek gerekir ki, ana babadna yukarıda sayılan sebeplerle velâyetin nez'i son tedbir olarak ele alı. nır. Daha önce önüne böyle bir mesele gelen hâkim ana babaya yol gösterecek, direktif verecek, talimat verecek ve ihtarda bulunacaktır (37). Yani ana babaya ödevlerini hatırlayıcı tedbirler, alacak. tır. Bütün bunlar faydasız kalırsa, hâkim son tedbir olarak velâyetin nez'ine karar verecektir. Fakat ana babanın akıl hastası olması, ayyașlığı ve belki de suihale sahip olması halinde hâkimin başka tedbirlere bașvurmadan velâyeti ana babadan nez'etmesi çocuğun menfaati icabidir.

b- Ana veya babanın yeniden evlenmesi :

Velâyetin nez'ini gerektiren diğer bir sebep te, boşanmadan sonra kendisine velâyet hakkı hâkim tarafından verilmiș olan ta. rafın yeniden bașka bir şahısla evlenmesi halidir (MK m. 275) Bu hal konumuzla ilgili olmadığı için burada üzerinde durulmayacaktur (38).

\section{3 - Çocuğa vasi ve bazı hallerde kayyım tayini :}

Onsekiz yaşını bitirmemiş olan çocuklar için aslolan velâyet altında bulunmak olduğuna göre bunların kanunî temsilcileri de ana ve babadır. Fakat eğer ana babadan velâyet nez'edilir veyahut ta çocuk ana ve babası olmaması dolayısıyla velâyet altında bulun-

(35) Fazla bilgi için bk. AKINTƯRK, Turgut : a.g.e. sh. 366 vd.

(36) Fazla bilgi için bk. VELIDEDEOGLU, H. V.: a.g.e., sh. 452 vd.

(37) Fazla bilgi için bk. VELIDEDEOGLU, H. V.: a.g.e., sh. 349 vd.

(38) Fazla bilgi için bk. AKINTỦRK, Turgut : a.g.e., sh. 299 vd. VELIDEDEOGLU, H. V.: a.g.e. sh. 354-355. 
mazsa çocuğa bir vasî tayin edilmek icap eder (MK. m. 354). Bazı belirli ve ender hallerde de çocuğa kaýym tayin edilebilir. Örneğin ana ve babanın çocuğun mallarını iyi idare edememesi halinde bu iyi idare edememe kendilerinden velâyetin nez'ini gerektirecek derecede değilse onlara idare hususunda yol göstermek üzere bir kayyim tayin edilir (MK m. 285/II).

Vasi tayini, kayyım tayinine nazaran daha genel bir tedbirdir. Kayyım tayini ise ancak belirli ve özel hallerde yapilır.

a- Çocuğa bir vasi tayini :

aa- Velâyetin nez'i halinde:

Ana babadan velâyet nez'edildiği zaman çocuğa bir vasi tayini gerekir (MK. m. 274/1). Bu hal, çocuğun özel durumunun gerektirdiği bir sonuçtur. Bir defa küiçük tam fiil ehliyetine sahip değildir. Bedenî ve fizikî yönden de büyük kişilere karșı daha zayıf durumdadır. Bu haliyle günlük yaşantısı içinde çeșitli zorluklarla karșı karşıyadır. Onun bu zorluklardan kurtulması için kendisini devam. lı olarak koruyan ve onu temsil eden, veli sıfatını taşıyan ana babadır. Eğer ana babadan velâyet nez'edilirse çocuk temsilcisiz ve koruyucusuz kalacaktır. Onun için bu gibi çocukların, kendilerini koruyup, hukukî işlemlerini onlar adina yapacak bir temsilciye ihtiyaçları vardır. Iş̧te çocư̆un muhtaç olduğu bu temsilci kendisine tayin edilecek olan vasidir (MK. m. 274/II). Velâyet müessesesi, vesayet müessesesine nazaran bir takım başkalıklar gösterirse de çocuğun korunmaya muhtaç olması böyle bir tedbiri zorunlu kılar (39). Vasi, kanunî temsilcisi olmak sıfatiyle çocuğun şahsî ve mamelekî durumu ile yakından ilgilenecek, gereken titizliği gösterecek, çocuk namına hukukî muamelelerini yapacaktır.

Vasi, bu işleri görürken veli gibi serbestçe hareket edemez. Vasinin üstünde kontrol ve murakabe vazifelerini gö.ren vesayet daireleri vardır ki bunlar sulh ve asliye mahkemeleridir. Vesayet maka. mı olan sulh mahkemesi, vasinin vesayet işlerini görürkenki işlemleri hakkındaki şikayetleri inceler (MK m. 404/1). Sulh mahkeme. sinin vesayetle ilgili olarak verdiği kararlara itiraz edilebilir. Itiraz edilecek makam asliye mahkemesidir (MK.m. 404/11, 432). Va sinin, vesayet alanındaki kiși adına yapacağı ișlemlerin bazılanna

(39) Velayet ve vesayet müessesesinin gösterdið̌i farklılklar hususunda fazla bilgi için bk. VELIDEDEOGLU H. V.: a.g.e., sh. 349 vd. 
sulh mahkemesi, bazılarına da sulh mahkemesi ile birlikte asliye mahkemesi izin verir (MK m. 405) (40). Vasinin yaptığı işlemle. rin rapor ve hesapların inceleyip tamamlanmasını ve düzeltilme. sini de sulh mahkemesi emredecektir (MK m. 407/1) (41)

bb - Velâyet altında bulunmayan küçüklere vasi tayini :

Bazı hailerde - çocuğun ańa babasının ölmesi, kayıp olması, çocuğu terketmesi gibi sebepler dolayısıyla - çocuklar velâyet al. tında değildirler. Bu gibi hallerde de bu çocuklara bir vasi tâyin edilmesi gerekir.

Nüfus, adliye ve idare memurları, görevleri dolayısiyle velâyet altında bulunmayan bir çocuğun varlığını ögrrenmişlerse bunu derhal sulh mahkemesine ihbar etmekle yükümlüdürler (MK. m: 354).

b - Çocuğa bir kayyım tâyini :

Çocuklara bazı belirli hallerde kayyım tâyin edilebilir. Bu haller çocuğun mallarının tehlikeye düşmesi (MK. m. 285/II), evli. lik dışında doğan çocuk hakkında bazı tedbirler alınması (MK. m. 298) bir işte kanunî mümessil ile çocư̆unn menfaatinin çatışma halinde bulunması veya kanunî mümessilinin bir maniinin çıkması halleridir (MK. m. 376). Çocuğa bir kayyım tâyininin gerektiren hallerden yalnız ilk ikisi konumuzla ilgili olduğundan sadece onlar üzerinde durulacaktır.

эa- Çocuğun mallarının tehlikeye dïşmesi :

Çocuğun şahsına ve mallarına dikkat ve ihtimam göstermekle mükellef olan ana ve baba gerekli dikkat ve titizliği göstererek çocuğun mallarını onun yararına olacak sekilde yöneteceklerdir Ana babanın bu mükellefiyetlerini gerektiği gibi yerine getirmemeleri sebebiyle çocugun malları tehlikeye düşer ve bu du. rumda bir takım tedbirler alınır ki bunlardan birisi de çocuğa bir kayyım tayinidir (MK. m. 285/II) (42) Bu kayyımlığn idare kayyımlığı olduğu fikri doktrinde hakimse de aslında idare kayyımı tayin edildiği kişiyi icabında temsil edebileceği gibi, temsil kayyl$\mathrm{m}$ da malların idaresine katılabilir bu bakımdan ikisi arasında bir

(40) Fazla bilgi için bk. AKINTÜRK, Turgut a.g. e. sh. 396 vd.

(41) Fazla bilgi için bk. AKINTÜRK Turgut : a.g.e., sh. 395-397.

(42) Bk. VELIDEDEOĞLU, H.V.: a.g.e., sh. 350. 
ayrım yapmanın pratik bir önemi yoktur (43). Egger'e göre bu eşit kayyımlığa "Tamamlayıcı kayyımlık» adını vermek daha uygundur. Çünkü küçüğün zaten kanunî mümessili vardır fakat özel sebepler dolayısıyla bunun yanında bir de kayym tayin edilmektedir (44).

Çocuğa bir kayyım tayinini gerektiren bir durumun ortaya çık. ması halinde, sulh mahkemesince çocuğa kendiliğinden veya ilgililerin başvurması üzerine bir kayyım tayin edilir. Kayyım kendisine verilen görevi sulh mahkemesinin talimatına uygun olarak yapar (MK. m. 402).

Çocuğa bir kayyım tayin edildiği zaman ana babadan velâyet nez'edilmiș değildir. Çocuğun mallarmın idaresi yine ana babada kalır, tayin edilen kayymm yalnız onlarin bu idaresine nezaret eder ve onlara yol gösterir (45).

bb- Çocuğun evlilik dıșında doğmuş olması :

Evililik dışında doğmuş bir çocuk ile anası arasındaki bağ, gayri sahih nesep bağıdır. Böyle bir çocuğa karşı anası, tıpkı sahih nesepli çocuklarına karșı haiz olduğu hak ve ödevlere sahiptir (MK. m. 311/II). Fakat velâyet ve çocuğun malları üzerindeki hak. ları bakımından değişik bir durum bahis konusudur (46). Ana, evlilik dışında doğan çocuğu üzerinde velâyet hakkını kanundan ötürü kazanmaz. Eğer çocuğun menfaatleri gerektiriyorsa, hâkim bu takdirde velâyeti anaya verebilir (MK. m. 311). Bunun gibi anann çocuğun malları üzerindeki hakları da kanundan ötürü değildir, hâkim tarafından tayin olunur (MK. m. 314). Fakat bu hakların, hâkim tarafindan tayin olunacắ̆ ana kadar belirli bir zaman geçebilir ve bu zaman içersinde bir temsilcisi olmayan evlilik dışı çocuğun çıkarları zarara uğrayabilir. Örneğin babalık davası çocuğun doğumundan itibaren bir yll içinde açılmalıdır. Bu süre içinde çocuğun fiil ehliyeti yoktur ve bu davayı kendisinin açmasına da imkân yoktur. Anası da velâyeti kanundan dolayı haiz olmadığından, hâkim velâyeti anaya verinceye kadar ana çocuğu temsilen dava açamaz. Böylece bir yıllık dava açılmaksızın geçerse çocuğun menfaatleri zarara uğrayabilir. Iște bunun önlenmesi ve çocuğun men-

(43) Bk. EGGER, Dr. A. (Çev.: Volf Çernis): Medeni Kanun Şerhi, Aile Hukuku, Üçüncü kısım, Vesayet, Ankara 1952, sb. 339.

(44) Bk. EGGER, Dr. A.: a. g.e. sh. 340-341.

(45) Bk. VELIDEDEOGLU, H.V.: a.g.e. sh. 351.

(46) Bk. AKINTURK. Turgut; a.g.e. sh. 337. 
faatlerinin korunması için hâkim, çocuğa hemen bir kayyım tayin etmek mecburiyetindedir (MK. m. 298). Kayyım tayin edildiģi çocuğu hukukî muamelelerinde temsil eder, onun adma dava açar veya çocuk aleyhine açılan davada onu temsilen hazır bulunur. Bu hal özellikle babalık davası açılması hallerinde önemlidir (47).

\section{§ III- HAKKINDA KORUNMA TEDBİRI ALINAN ÇOCU. GUN MAMELEKİ DURUMU}

\section{I- GENEL TEDBİR HALLERINDE :}

A- Çocuğun bir aile yanına yerleștirilmesi :

Korunmaya muhtaç çocukların yanlarına yerleştirildikleri aile. ler ile aralarındaki ilișki iki șekilde olabilir.

1- Aile çocuğu evlât edinmiş̧tir. Bu durumda Medenî Kanu. nun evlâtlık mukavelesiyle ilgili hükümleri uygulanacaktır. Çocuğu evlâtlık olarak alan şahıs kanundan ötürï onun velisi sayllır (MK. m. 257). Çocuk ta evlât edinenin sahih nesipli füruğu durumundadır. Eviâthk olarak alınan korunmaya muhtaç çocuğuı malları varsa, bunların yönetimi, veli, yani kanunî temsilci sıfatıyla evlât edinene düşer. Zaten Medenî Kanunun 257 nci maddesinde ana babanın çocuk üzerindeki yetkilerinin evlât edinene geçeceği bildirilmektedir.

2- Aite çocuğa bakmak üzere yanına almıştır: Bu durunıda «Koruyucu aile» bahse konudur. Çocuk velâyet altında bu!unmadı̆̆ından ve çocuğu yanına alan aile de onun temsilcisi sıfatına sahip olmadığından çocuğa bir temsilci tayin edilir. Bu temsilci vasi olacaktır. Çocuğu, bakmak üzere yanlarına alan aile fertleri vasî tayininde tercih edilebilirler. Zaten Medenî Kanunumuz velâyet altında bulunmayan küçüklere bir vasi tayin edileceğini açıkca bildirmiştir (MK m. 354).

Çocuklarn bakılmak ve yetiştirilmek üzere bir aile yanına yerleştirilmesi halinde çocukla, çocư̆a bakmak üzere yanına alanlar arasında gerek tabii ve gerekse suni - evlâtlık bağı bir nesep bağı meydana gelmez. Bunun içindir ki bu çocuklar velâyet altında olmayan çocuk durumundadırlar. Çünkiu ya ana babaları yoktur, ya da bunlar belli değildir, veya ana babaları

(47) Bk. AKINTÜRK, Turgut; a.g.e. sh. 321. 
tarafından terkedilmişlerdir, yahut ta ana babadan velâyet nezedilmiştir. Iş̧te bu gibi çocuklara kendilerini temsil etmek üzere bir vasi tayin edilir. Çocuğa bir vasi tavin edilince, varsa çocuğun mallarını, kanunî temsilci sıfatiyle bu vasi yënetecektir. Netekim 1972 sayll Kanunda «Haklarında korunma tedbiri alınan çocukların mallarının kimler tarafından idare edileceği Türk Medeni Kanunu hükümlerine göre tayin edilir» denilmektedir (KMÇHK m. 3/II).

B- Çocuğun bir müesseseye yerleștirilmesi :

Çocuğun bir müesseseye yerleștirilmesi halinde bu müesseseler tarafından çocuklar bakılıp yetiștirilmekte, bir iş ve meslek sahibi edilmekte ve eğer varsa malları, paraları ile şahısları himaye edilmektedir (KMÇHK m. 18, 19, 20, 26). Hal böyle olunca çocuğun ayrıca bir kanunî mümessile ihtiyacı yokmuş gibi bir fikir uyanabilir. Fakat 6972 saylı kanunun 3 üncü maddesinin ikinci fıkrasında, haklarında korunma tedbiri alınan çocukların mallarının Medenî Kanun hükümlerine göre idare edileceği açıkca belirtilmektedir. Medenî Kanun hükümleri gereğince de bu gibi çocuklara bir vasi tayin edilmesi gerekir (MK. m. 273). Böylece bu çocukların mallarımı da kanunî mümessil sıfatıyla tayin edilecek olan vasi idare edecektir.

\section{II- ÖZEL TEDBIR HALLERINNDE :}

A-- Çocuğun bir şahıs yanına yerleștirilmesi :

Bt durumda genel tedbirlerden olan aile yanına yerleștirilen çr,cuğun mallarının idaresi hükümleri burada da aynen uygulanacaktır (48).

B- Velâyetin nez'i :

Velâyet nez'edilince çocuğa bir vasî tayin edilir (MK. m. 274/HI) Çocư̆un kanunì mümessili sıfatıyla mallarını da bu vasi idare edecektir.

C-- Çocuğa bir kayyım tayini :

Ana baba, çocuğun mallarını gerektiği gibi yönetmemişler ve bu yüzden çocư̆a bir kayyım tayin edilmiș ise, çocuğun velâyeti ve mallarının idaresi yine de ana babada kalır. Kayyım sadece ana

(48) Bk. sh. 211 «Çocuğun bir aile yanına yerleștirilmesi». 
babaya nezaret eder ve onlara yol gösterır (49). Eğer evlilik dışı bir çocuk bahis konusu ise ve kendisine bir kayyım tayin edilmiş. se, hâkim tarafından çocuğun anasına velâyet hakkı verilinceye kadar çocuğu bu kayyım temsil eder. Eğer varsa çocuğun mallarını da bu kayyım yönetir. Burada ki kayyım daha ziyade temsil kay. yımı mahiyetindedir.

\section{$\S$ IV- KORUNMA TEDBİRLERINIIN ALINMASINDA TA- KIP EDILECEK USUL}

\section{I- KORUNMAYA MUHTAÇ ÇOCUK TARIFJNE GIRME HUSUSU :}

Bir çocuk hakkında korunma tedbiri alınabilmesi için o çocuğun her şeyden önce "Korunmaya muhtaç çocuk» tarifine girmesi gerekir. Küçügüun; bedenî, ruhî, ahlâkî ve fikrî gelişmeleri tehlikede olup, ana babasının olmaması, ana babasının belli olmaması ve. ya ana babası tarafindan terkedilmesi, yahut ta ana babası olmakla beraber ana babası tarafından fuhșa, dilenciliğe, alkollü içkileri ve uyuşturucu maddeleri kullanma alışkanlığına veya serseriliğe itilen veya ana babanın çocuk üzerindeki vazifelerini yerine getirmekten aciz olmaları veya kasden yerine getirmemeleri dolayısıyla ana babadan velâyet hakkı nez'edilmiş bir çocuk olması gerekir.

\section{II-- HAKIM HÜKMU் :}

Korunmanın belli bașlı șartlarından birisi de hâkimin bu yolda karar vermiş olmasıdır. Yalnız burada kasdedilen korunma, devamlı olan tedbirlerle korunmadır. Yoksa-çocuk hakkında hâkim tarafından karar verilinceye kadar, çocuğun durumu acilse, mahallin en yüksek mülkî amiri çocuğu hâkim hükmü elde edilinceye kadar geçici olarak bir yere yerleştirebilir. daha önce incelenen geçici tedbirler için bu șart bahis konusu değildir.

Hâkim hükmünün gerekliliği gerek Medenî Kanun, gerekse 6972 sayılı Kanunda öngörülmüștür. Medenî Kanun 273 ve sonraki maddelerinde öngörülen tedbirlerin hâkim tarafından alınacağı belirtilmiștir. 6972 sayılı kanun da «Mahallin sulh hukuk hâkimliğinde gerekli tedbirler ittihaz olunur» demektedir (KMÇHK. m. 1) 6972 sayılı Kanuna göre hâkimin karar verebilmesi için bu yolda

(49) Bk, VEL.IDEDEOĞLU, H.V.: a.g.e., sh. $351 \mathrm{vd}$. 
kendisinden bir talepte bulunulmalıdır. Bu talebi mahallin en yük. sek mülkî amiri yapacaktır.

Bilindiği gibi korunmaya muhtaç bir çocuğun varlığından haberdar olan belediye, zabita ve devlet memurları, durumu mahal. lin en yüksek mülkî amirine bildirmek zorundadırlar. Mahallî mül. kî amir de çocukla ilgili bir dosya hazırlanması için gerekli kişile. re ve makamlara emir verir (50). Dosya hazırlandiktan sonra mahallî mülkî amir bu dosyayı o mahâldeki sulh hâkimine gönderir. İște bu dosyayı gönderirken çocuk hakkında korunma kararı alinması hususunda da bir talepte bulunur.

Hâkim, çocuk hakkında hazırlanmış olan dosyayı inceler, ge!ekli görürse șahitleri dinler ve bundan sonra çocuğun durumu getektiriyorsa hakkında korunma kararı verir. Eğer çocuk korunma. y1 gerektirecek bir durumda değilse, hâkim, korunmanın lüzum. suzluğuna karar verir. Korunmaya muhtaç çocuk hakkında, hâkim kararının alınması nizasız kazaya tabidir.

A-- Yetkili ve görevli mahkeme:

1- Yetkili mahkeme:

Korunmaya muhtaç çocuklar hakkındaki 6972 sayıh Kanun Mahallin en yüksek mülkî amirinin bu hususta, o mahaldeki sulh hâkimine bașvuracağını belirtmektedir (KMÇHK. m. 2). O halde yetkili mahkeme: Mahallî mülkî amirin bulunduğu yerdeki mahkemedir. Mahallî mülkî amire, durumu o mahaldeki, belediye, zabı. ta ve devlet memurları haber vereceğine göre korunmaya muhtaç çocuk ta o yerde bulunmakta veya o yerde çocukla ilgili bir işlem yapilmaktadir.

\section{2- Görevli Mahkeme :}

Yetkili mahkemeyi tespit edebilmek kolaydır. Fakat, görevli mahkemeyi tespit edebilmek için "Ana babası belli olan çocuklar» ve "Ana babası belli olmayan çocuklar» ayrımın yapmak gerekir.

a- Ana babası belli olan çocuklar :

Medenî Kanuna göre bu hususta görevli olan mahkeme asliye hukuk mahkemesidir. Netekim 5387 saylı eski korunmaya muhtaç

(50) Fazla bilgi için bk. sh. 185 vd. 
çocuklar hakkındaki Kanunun yürürlü̈̆̈ü zamanında Adalet Bakanlığı tarafından verilen bir mütalâa ile Medenî Kanunun bu hükmü. ne uyan bir çözüm yolu kabul edilmiştir (51). Bu mütâla, Millî Eğitim Bakanlığının isteği ile verilmiştir ve ana babası bełli olan çocuklar hakkinda asliye, ana babası belli olmayan çocuklar hakkında da vesayet makamını, yani sulh mahkemesinin görevli olduğu kabul edilmiştir. 5387 sayılı kanun sadece mahkemeden bahsetmekte, görevli mahkemenin hangisi olduğunu belirtmemekte idi. $\mathrm{Bu}$ durum karışılıklara ve görevli mahkemenin tespiti hususunda değișik fikirlerin ortaya çikmasına sebep olmuştur. Yargztay IV. Hukuk dairesi bir kararı ile bu karışıklıklara bir çözüm yolu getirmiş ve ana babası belli olmayan çocuklar için görevli mahkemenin sulh hukuk mahkemesi olduğunu bildirmiştir (52). Daha sonra da Adalet Bakanlığı adıgeçen mütalâa ile ayni görüsşe katılmıştır. 5387 sayılı Kanun zamanında durum böylece çözümlenmiştir.

5387 sayılı Kanunu yürürlükten kaldıran, 6972 sayılı Kanun bu meseleyi karışıklıklara meydan vermeyecek şekilde düzenlemiş ve görevli mahkemenin sulh hukuk mahkemesi olduğunu belirtmiştir (KMÇHK. m. 1).

6972 sayılı Kanun görevli mahkemeyi tespit eden hükmünde. korunmaya muhtaç çocukları kategoriler halinde saymıș ve bu arada «Ana babası tarafından ihmal edilip, fuhşa, dilenciliğe, serseriliğe, alkolläi içkileri ve uyuşturucu maddeleri kullanma ahşkanlığına yöneltilen çocuklar» hakkında korunma kararı almak hususunda sulh mahkemesinin görevli olduğunu bildirmiștir. Halbuki bu maddenin ifade tarzından da anlașıldığı gibi, burada bahse konu olan çocuklar ana babası olan çocuklardır. Ve bu çocukIar velâyet altındadırlar. Bunun için bu çocuklar hakkında asliye mahkemesinin görevli olması gerekirdi. 6972 saylı kanunun 1 inci maddesi bu yolda düzeltilmeli ve Medenî Kanunla arasında bir ahenk kurulmalıdır. 6972 sayılı Kanuna bu hüküm konulurken, daha önce Adalet Bakanlığı tarafından verilen mütalâa ve Medenî Kanun hükümlerinin farkına varılmamıștır. 6972 sayılı kanundan önceki durumda ana babası olan çocuklar hakkında asliye mahkeme si görevli kılınmıştır-.

(51) Adalet Bakanlığı, Hukuk Ișleri Genel Müdürlüğii, 8.11.1950 tarih ve $78-20$ sayılı müitalâa, 16.2 .1950 tarih ve 49-105 sayılı mütalâa.

(52) Yargitay IV. Hukuk Dairesi 26.1.1950 tarih ve 2279-408 sayl. 
b- Ana babası belli olmayan çocuklar:

Bu hususta herhangi bir karıșıklık söz konusu değildir. Gerek 5387 sayıl eski Kanun zamanındaki uygulama ve gerekse 6972 sayıl Kanun hükümleri bakımından bu husustaki görevli mahkeme sulh mahkemesidir (53).

\section{B- Hâkimin takdir hakkı :}

Kanun önünde hâkime tanınan serbestilerden birisi de hâkimin kanun karşısında, takdir hakkına sahip olabilmesidir. Modern Hukuk Teknighi bakımından, meselelerin bilhassa kazüistik bir yolla ele alınmasinın sakıncalı olduğu hallerde bu serbestinin önemi bir kat daha artmaktadır. Hele korunmaya muhtaç çocuklar bahse konu olunca, hâkimin takdir hakkı vazgeçilmez bir unsur olarak karșımıza çıkar. Bir kere hâkim, kendisinden korunma kararı vermesi isteminde bulunulunca, çocuk hakkındaki dosyayı ve çocugun durumunun hakikaten korunmayı gerektirip gerektirmediğini inceleyecektir. Eğer çocuğun durumu hakikaten korunma tedbiri alınmasını gerektiriyorsa hâkim bu yolda karar verecektir. Hâkim, bu kararı verirken sadece çocuk hakkında hazırlanan dosyayı incelemekle yetinmiyecek, çocuğun şahsi durumunu ve içinde bulunduğu çevrenin şartlarını da göz önünde tutacaktır. Zaten 6972 sayılı Kanunda, hâkimin çocuk hakkında hazırlanan dosyası inceledikten sonra eğer durum gerektiriyorsa korunma karan vereceği belirtilmektedir (KMÇHK. m. 2). Diğger taraftan Medenî Kanunun bu konuyla ilgili hükümlerinde de hâkime takdir hakkı tanıyan bir düzenleme mevcuttur. Örneğin Medenî Kanunun "Çocukların yerleștirilmesi" kenar başlığı ile ifade edilen hükmünde, eğer gerekti. riyorsa hâkimin çocuğu bir aile yanına veya bir müesseseye yerleştirebileceği belirtilmektedir. Burada "yerleștirebilir» tabiri hâkime tanınan takdir hakkının geniș bir ifadesidir (MK. m. 273). Fakat hâkimin takdir hakkına sahip olması demek onun tamamen bașıboş bir surette keyfî kararlar alması demek değildir. Hâkim, takdir hakkını kullanırken «hak ve nısfet»le hareket edecektir (MK. m. 4). Yani hâkìm önüne gelen hadiseyi tarafların durumuna en uygun gelen şekilde ve hukukun genel kurallarma ve gayesine uygun olarak halledecektir (54).

(53) Bk. Adalet Bakanlı̆̆ının ilgili mütalâaları, sh. 215, dipnot.

(54) Fazla bilgi için bk. AKIPEK, Jale, G, : a.g.e. sh. 134 vd. 


\section{§ V - KORUNMA SÜRESI}

\section{I - KORUNMANIN DEVAM EDECEGI ASGARI SÚRE :}

Korunmanın asgarî süresinin ne olacağı hakkında 6972 sayılı Kanunda herhangi bir hüküim yoktur. Ancak Medenî Kanunda ön. görülen ve «Özel tedbirler» başlığı altında incelenen, velâyetin nez'i tedbirinde bu tedbirin mahiyetine uygun olarak devam edeceği bir asgarî süre tespit edilebilir. Velâyetin nez'i ancak Medenî Kanunda öngörülen sebeplerin mevcudiyeti altında uygulanan bir tedbirdir (MK. m. 273) (55). Medenî Kanun hükümleri gereğince, velâyetin nez'ini gerektiren sebep ortadan kalkunca hâkim velâyeti ana babaya tekrar iade eder (MK. m. 276/II). Lâkin velâyetin ana babaya tekrar iade edilmesi için nez'iden itibaren bir yll geçmiş olma. lıdır (MK. m. 276/II). Yine özel bir tedbir olan çocuğa bir kayyım tayini halinde de asgarî bir süre göze çarpar. Bilindiği gibi evlilik dışında doğan çocukların üzerinde anaları doğumla kanundan do. layı velâyet hakkına sahip olmazlar. Bu çocuklar üzerinde analarının velâyet hakkına sahip olmaları ancak hâkim hükmü ile olur. (MK. m. 311). Ancak velâyet hakkının anaya verilmesine kadar çocuğu temsil etmek üzere kendisine bir kayyım tayin edilir (MK. m. 298). Çocư̆a bu yolla tayin edilen kayyımın görev süresi, hâkim tarafından anaya velâyet hakkının verilmesine kadar devam eder. Burada da anaya velâyetin verilmesi anına kadar sınırlandınlmıș asgarî bir tedbir süresi var demektir. Fakat bu süre velâyetin nez'i halindeki gibi kesin olarak - bir yıl gibi-sınırlandırılmıș değildir. Yani hâkim, ne zaman anaya velâyet hakkını verirse, tedbir de en çok o ana kadar devam edecektir.

\section{II- KORUNMANIN DEVAM EDECEĞI AZAMÎ SÜRE :}

Bu hususta hem Medenî Kanunda ve hem de 6972 sayılı Kanunda hüküm vardır. Daha önce de incelendiği gibi korunmanın bir şartı da çocuğun küçük olması idi. Bu şarttan korunmanın azamî süresini çıkarmaktayız. 6972 sayılı Kanunda öngörülddüği gibi korunma, çocuk reşit oluncaya kadar devam edecektir (KMÇHK. m. 1).

Medenî Kanuna göre temyiz kudretine sahip olan çocuk, reșit olmakla tam fiil ehliyetini de iktisap eder, yani tam ehliyetli bir kişi durumuna girer (MK m. 11/I, 11/II, 12) (56).

(55) Bu hususta fazla bilgi için bk. sh. 203 vd.

(56) Fazla bilgi için bk. AKINTURK, Turgut : a.g.e. sh. 406. 
Normal olarak korunmanın azami süresi, çocuğun rüşde ermesi, ile sımırlandırılmıștır. Fakat bundan hariç tutulan haller de vardır. Korunma bazen rüșdden evvel sona erebilir, bazen de rüşdün kazanilmasından sonra da devam eder.

6972 sayıl Kanuna göre lïzum görüldügüi hallerde korunma, ilgililerin teklifi üzerine, çocuk reşit olmadan mahkeme tarafından kaldırilabilir (KMÇHK. m. 3/III). Bu haller artık korunmaya lüzum kalmadığı hallerdir.

Kanun çocuğun reşit olmasına rağmen korunmanın bundan sonira da devam edebileceğini kabul eder. Korunmanın rüşden sonra da devam edebilmesi için önce çocugun rızası alınır, sonra bu hususta karar elde etmek için ilgiliterce mahkemeye başvurulur.

Haklarında reșit olduktan sonra da korunma devam edecek olan çocuklar; çeşitli sebepler yüzünden henüz hayatlarını kazanacak durumda olmayan çocuklardır. Illgili kişiler, çocuğun korunması ile mükellef olan yurt idareleri ve birlik meclisidir.

\section{$\S$ VI - KORUNMANIN SONA ERMESI}

Korunmanın sona ermesi, çeșitli sebeplerle çocuk hakkında alınan korunma tedbirlerinin ortadan kalkması veya kaldırılması demektir. Bundan böyle artık çocuğun korunması için alman tedbirler devam etmeyecektir. Sona erme çeşitli şekillerde olabilir.

\section{I - SONA ERME ŞEKİLLERI :}

A- Kendiliğinden sona erme:

1 - Ölüm ile :

Tabiî bir olay olan ölüm sonucunda korunmanın konusu olan çocuk, bir hukuk süjesi, yani bir şahıs olarak tamamen ortadan kalkar. Bu durumda korunmanın konusu ortadan kalkınca korunma da kendiliğinden sona erer.

2 - Kanundan ötürü :

Gerek 6972 sayll Kanunun açık hükmü (KMÇH. m. 1) ve gerekse Medenî Kanun gereğince alınan tedbirlerin mahiyeti icabı korunma, çocuğun rüşde ermesi ile, yani onsekiz yaşııı bitirmesi ile sona erer. Bu sona erme hali için ayrıca hâkim hükmüne ihtiyaç 
yoktur. Çocuk reşit olmakla-eğer mümeyyizse-tam ehliyetli bir sahıs haline gelir. Bundan böyle her türlü hukukî muamelelerini kendisi yapar, haksız füillerinden mesul olur, mameleki üzerinde her türlü tasarruflarda bulunabilir. Reşit olan bu çocuklar hakkndaki korunma tedbirleri de artık kendiliğinden kalkar.

B- Hâkim hükmüi ile sona erme :

1 - Nez'edilen velâyetin iadesi halinde :

Medenî Kanunda yazılı sebepler karșısında, hâkim ana babadan velâyeti nez'eder (MK. m. 274 vd.). Yahut çocuğu ana babanın yanından alarak bir aile yanına veya bir müesseseye yerleștirir (MK. m. 273). Yine Medenî Kanun gereğince velâyetin nez'ini gerektiren sebepler ortadan kalkmıșsa, hâkim, doğrudan doğruya veya ana babanın isteği üzerine velâyeti kendilerine iade eder ( $\mathrm{MK}$. m. 276). Velâyetin nez'i daha önce de incelendiği gibi özel korunma tedbirlerindendir. Nez'edilen velâyetin iadesi ile bu tedbir de sona ermiş olur. Velâyet hâkim tarafından ana babaya iade edileceğinden bu tedbir hâkim hükmü ile ortadan kalkmış olur.

\section{2 - 6972 sayılı Kanun gereł̆ince}

Adı geçen Kanunun birinci maddesinin birinci fıkrasına göre alınan korunma tedbirlerinin lüzum görüldüŭgü takdirde çocuk rcsit olmadan kaldırılabileceği belirtilir (KMÇHK. m. 3/III). Bunun için ilgili şahıslar - bundan çocuğun bakım ve yetiştirilmesinden mes'ul olan birlikler veya yurt idarecileridir- teklif edecek ve hâkim kararın kalkması hususunda karar verecektir. Çocuk reşit olmadan önce korunma tedbirinin kaldırılabileceği haller, çocuğun, korunmaya muhtaç bir çocuk durumundan çıması veya korunma tedbirlerinin artık fayda saglamaması gibi haller olabilir. Bu ortadan kalkiş halinde de 6972 sayıl Kanun gerełince hâkim hükmü gereklidir. (KMÇHK. m. 3/III).

3 - Medenî Kanunun 414 üncü maddesi gereğince :

Medenî Kanunun 414 üncü maddesi gereğince, küçükler hakkında verilmiş olan vesayet kararı, rüșt veya hâkimin kazaî rüş̧e karar vermesiyle sona erer. Maddede iki türlü rüşt bahis konusudur. Normal rüsșt ve Erken rüşt.

a- Normal rüişt :

Her şahıs onsekiz yaşını doldurmakla rüşde ermiş olur (MK. m. 11). Bundan böyle kişi, —eger mümeyyiz ise- - tam fỉil ehliyetini 
haiz olur ve bütün hukuki işlerini tek başına yapabilir. Rüşde ermeden önce kişi, tam fiil ehliyetine sahip olmadığı, kendisini temsil ve himaye edecek bir temsilciye muhtaç olduğu için velâyet altında değil ise kendisine bir vasi tayin edilir. Iște mümeyyiz çocuk, reşit olmakla tam fiil ehliyetine sahip hale geldiğinden ve artık himayeye muhtaç olmadığından hakkındaki tedbir, yani vesayet altında bulunma hali de sona erer. Bu çeșit normal rüșde ermek için hâkim hükmüne ihtiyaç yoktur.

$\mathrm{b}$ - Erken rüsst :

Bu rüşde erme hali, çocuğun onsekiz yaşın doldurmadan reșit olmasıdır. Bu da iki şekilde olabilir :

aa- Evlenme ile reșit olma :

Çocuk, aslında normal rüșt şartına, yani onsekiz yaşını doI. durma şartına sahip olmadığı halde eťger evlenme rüşdüne sahipse kanunî mümessilinin rızası ile evlenebilir. Medenî Kanuna göre de evlenme kişiyi reşit kıldığı için (MK. m. 11/II) kişi onsekiz yaşından önce reşit olur (57).

\section{bb- Kazaî rüsșt :}

Onbeş yaşını bitiren bir küçük, kendi ruzası, ana babanın mu. vafakat ${ }_{1}$ ve asliye mahkemesinin karan ile reşit kılınabilir (MK. m. 12). Fakat burun için olağanüstü haller bahis konusu olmalı. dır (58). Bu reșit rüsşde ermede hâkim hükmü gereklidir. Hâkim hükmü doğrudan doğruya tedbiri ortadan kaldırmaz fakat tedbirin ortadan kalkmasını gerektiren durumu, yani rüşdü doğurur.

\section{II - SONA ERMENIN HÜKÜM VE NETICELERT :}

Korunmanın sona ermesinin, bir çocuğun şahsı, bir de çocu* gun malları bakımından olan iki türlü neticesi vardır.

$$
\begin{aligned}
& \text { A-Çocuğun şahsı bakımından o l a n } \\
& \text { sonuçIarı: } \\
& 1 \text { - Korunmantn kendiliğinden sona ermesi halinde: }
\end{aligned}
$$

Korunma, çocuğun reşit olması ile, kanundan ötürü kendili. ğinden sona ermis olur. Bu hal çocuğun şahsî durumu üzerinde bir takım değișiłklikler meydana getirir. Bir kere çocuk, reşit of

(57) Fazla bilgi için bk. AKINTÜRK, Turgut : a,g.e. sh. $58 \mathrm{vd.}$

(58) Fazla bilgi için bk. AKIPEK, Jale G.: a.g.e. sh. $64 \mathrm{vd}$. 
makla, velâyet altında ise velâyetten, vesayet altında ise vesayet. ten kurtulacaktrr ve sayet mümeyyiz ise tam fiil ehliyetine sahip bir kişi haline gelecektir. Böyle bir kişi, her türlü hukukî işlemlerini yalnızca kendisi yapabilecek, her türlü hakkını kullanabilecek ve her türlü edimi yüklenebilecektir (59).

Bundan başka çocuk, bir şahıs veya bir aile yanına yerleştiril. miş ise bu șahıs veya ailelerin çocuk üzerindeki bakım ve yetiş. tirme mükellefiyetleri ve çocukla olan ilișkileri sona erecektir.

Çocuk eğer bir kurulușa yerleştirilmiş ise reșit olmakla ko. runma tedbirleri sona ereceğinden bu kurulușların çocuklar üze. rindeki koruma ve ihtimam mükellefiyeti de sona erecektir.

2 - Korurmanın hâkim hükmüi ile sona ermesi halind: :

Korunma hâkim hükmü ile sona ermişse bu takdirde korunma. nun kendiliğinden sona ermesi halindeki sonuçlar burada uygula. namaz. Örneğin, nez'edilen velâyet ana babaya iade edilmişse, çocuk henìz reşit olmadığından ana babanın çocuk üzerinde kanun. dan doğan himaye ve onu temsil yetkileri devam edecektir. Yanj bu durumda hâkim hükmüne dayanan korunma ortadan kalkmakta, kanundan ötürü ana babaya düșen koruma zorunluğu onun yerini almaktadır :

6972 sayılı Kanun gereğince de çocuk reşit olmadan ilgililerin talebi ve hâkim hükmiu ile korunma tedbiri sona erebilir (KMÇHK m. 3/III). Bu durumda da çocuk eğer velâyet altında değil ise re. şit oluncaya kadar kendisine bir vasî tayin edilmesi gerekir. Bu durumlarda velî veya vasînin çocuk üzerindeki kanundan doğan himaye ve temsil yetkisi devam edecek ve çocuk henüz tam fiil ehliyetine sahip olamnyacaktır. Çocuğun hukukî işlemlerini onun adına kanunî temsilcisi yapacak, yani onu temsil edecek, onun şahsına gerekli dikkat ve ihtimamı gösterecektir.

B - Çocugunmallaribakimindan ol an sonuçları:

1 - Korummanın kendiliğinden sona ermesi halinde :

Ana babasından velâyet nez'edilen çocư̆ga bir vasi tayin edilir (MK. m. 274/II). Çocuğun şahsî malları varsa bu malların yönetí.

(59) Fazla bilgi için bk. AKIPEK, Jale G. : a.g.e. sh. 50 vd. 
mi de vasîye düșer. Vasî, çocuğun mallarım, çocuğun menfaatlerine uygun bir şekilde idare etmekle yükümlüdür.

Vesâyet, eğer çocuk mümeyyiz ise, reşit olmasına kadar devam eder. Çocuk reşit olmakla tam fiil ehliyetine sahip hale gelir ve vesayetten kurtulur. $O$ ana kadar çocuğun mallarını yönetniş olan vasi, vesayetin sona ermesi ile bir kesin hesap ve idaresine ait bir rapor hazırlayarak bunları sulh mahkemesine, yani vesayel makamına verir (MK. m. 433). Vasînin, çocuğun mallarını yönetirken bu mallara verdiği zararlardan dolayı kanundan doğan bir mesuliyeti vardır $(60)$.

Iște çocuğun rüşde ermesi ve vasînin sulh mahkemesine hesap vermesinden sonra çocuk kendi mal varlı̆g üzerinde yalnızca, tek başına her türlü hukukî ișlemleri yapabilir, mallarını dilediği gibi yönetebilir. Çünkü artık tam fiil ehliyetine sahiptir (61).

Eğer çocuk, velâyet altında ise rüşde ermekle hakkındaki ted. bir de ortadan kalkacağı için, mallarnnın idaresi bundan böyle kendisine düşecektir. Fakat bu durumda çocuğun velîleri, vesâyet altında bulunan çocuğun vasîsinin vesâyet makamına verdiği gibi bir hesap verme durumu ile karşı karşıya kalmıacaktır. Zaten velî çocuğun mallarını kötii yönetiyor ise daha önce incelendiği gibi çocuð̆a bir kayyım tayin edilirdi.

Çocuk, 6972 saylı Kanunda öngörüldüği șekilde bir aile ya. nına, bir kuruluşa ve dolayısıyla bir atölye veya ișyerine yerlești. rilmişse çocuğun rüșde ermesi ile tedbirler de ortadan kalkacă̆mn. dan acaba çocuğun mallarının yönetimi ne olacaktır?. Gerek ço. cuk reşit oluncaya kadar ve gerekse reşit olduktan sonra şahsi mallarının ne olacağ 6972 sayılı Kanunda hükme bağlanmıștı (KMÇHK m. 18, 19, 20. 26).

Eğer çocuk bir atölye, bir ișyeri veya özel kișiler yanında biı ücret karşılığında çalıșıyorsa, çocuğun bu ișten elde ettiği gelir çocuk adına millî bankalardan birinde ậtırilacak bir hesaba yatı. rılır (KMÇHK. m. 18). Ancak, bu gelirden belirli bir kısmı, çocuğıın bakılma masraflarına katılma payı olarak çocuğın bağlı bu. lunduğu birlikçe tespit edilerek alkkonulur. Artakalan paradan yi. De birlikçe tayin edilen miktar çocuğun harçlığı olarak ayrlır ve geri kalan para çocuk adına bankaya yatırılır (KMÇHK. m. 18).

(60) bk. AKINTURK, Turgut: a.g.e. sh. 399 vd.

(61) bk. VELIDEDEOGLU, H.V.: a.g.e. sh. $492 \mathrm{vd}$. 
Bundan başka çocuk, köylerde veya çiftçiler yanında aynî üicret karșılığında çalışıyorsa, çocuğa verilen ücretlerden paraya çevri. lebilenler çevrilerek çocuk adına bankaya yatımlır. Paraya çevrilemiyenler ise, köy ihtiyar kurullarnnca değerlendirilerek çocuk ad1na saklanır (KMÇHK. m. 19). Çocukların paralarını zamanında bankaya yatırmayan sorumlular için 6972 sayıl Kanun para ve hapis cezaları öngörmektedir. Çocuk reşit olunca onun adına saklanan bu para ve mallar kendisine verilir. Bundan böyle tam fïl ehliyetine sahip olan çocuk malların kendisi idare edecektir.

2 - Korunmanın hakim hükmï ile sona ermesi halinde :

Çoctuk henüz rüşde ermeden hakim hükmü ile korunma tedbiri kalkmıșsa ne olacaktır? Çocư̆un ana babasından velâyet nez'edilmiş ise kendisine bir vasî tayin edileceựinden malların yönetimi de vasîye düşer. Fakat velâyetin nez'i sebepleri ortadan kalkmıs ve hakim velâyeti ana babaya geri vermişse bu durumda * kanunî mümessil sıfatıyla çocuğun mallarını ana baba yönetecek. tir. 6972 sayll Kanunda belirtildiği gibi, ilgililerin isteği üzerine hâkim kararı ile çocuk reşit olmadan önce tedbir kaldırılırsa, velâyet altında bulunmayan çocuğa bir vasî tayin edilir. Bu durumda da çocư̆un mallarının yönetimi yine vasîye düșer.

\section{$\S$ VII - TEŞKILÂT :}

Korunma teşkilâtı ile korunmaya mulhtaç çocuklar alanında faaliyet gösteren her türlii organ, kiși ve makam krasdedilmektedir. Bunlar, bilfiil korunma işlerinde doğuudan doğnuya hizmet gören yönetim onganlan şeklinde olabildiği gibi, bu yönetim organlannı kontrol eden, denetleyen organlar da olabilirler. Bunlann yanında denetim ve yönetim görevi ifa etmemekle beraber danışma kurulu olarak görev ifa eden teşkilât ta mevcuttur.

\section{I - YÖNETİCI ORGANLAR :}

Yönetici organlardan maksat, korunmaya muhtaç çocuklar hakkında alınacak tedbirler alanında doğrudan doğruya görev yapan teşekküller veya kişilendir. Bunlandian başlıcası : birlikler, mahallî mülkî amir ve birliklere bağlı olan kuruluşlardır.

$$
\text { A - Birlikler: }
$$

Korunmaya muhtaç çocuklarla ilgili olarak birliklere yer ve. ren ilk kanun 6972 sayll Kanundur. Evvelce yürürlüktte bulunan 
5387 sayll Kanunda sayılan teșkilât arasında birlikler adı altında hir kuruluș öngörülmemiștir. 5387 saylı Kanuna göre korunma. ya muhtaç çocuklar hakkındaki tedbirleri, köylerde muhtar ve ih. tiyar heyetleri, belediyesi olan yerlerde de belediyeler almakla mü: kellefdi. Yeni bir düzenleme şekli getiren 6972 sayllı Kanun ise bu alanda görevli organlar olarak birliklerden bahsetmiştir. Fakat birlik denilen teşkilât ilk defa 6972 sayılı Kanunla da getirilmiş değildir. Bunlar daha önce Belediyeler Kanunu ile düzenlenmișler. dir (Bel. K. m. 133-148), 6972 sayll Kanunla da kendilerine ko. runmaya muhtaç çocuklar alanında görevler yüklenmiștir.

Birlikler, 6972 sayıl Kanun hükümlerine göre, korunmaya muhtaç çocukların bakım ve yetiştirilmesi ve bir meslek sahibj edilmeleri için İl özel idareleri ve belediyeler tarafından ortaklaşa kurulurlar (KMÇHK m. 4). Birlikler tïzel kişiliğe sahip kuruluş. lardır (Bel. K. m. 138). Millî Eğitim, Sağlık ve Sosyal Yardım bakanlıkları bu birliklere her türlü yardımda bulunmakla mükellef. tirler ( $\mathrm{KMÇHK} \mathrm{m.} \mathrm{4/I).} \mathrm{Birlikler,} \mathrm{il} \mathrm{özel} \mathrm{idareleri} \mathrm{ile} \mathrm{belediyeler}$ tarafindan müștereken kurulur. Belirli bir yerde bu birliklerin kurulması mümkün olmazsa Millî Eğitim ve Sağlık ve Sosyal Yar. dım bakanhklarının oyu alınarak çevredeki illerde kurulabilir (KMÇHK. m. 5/II). Birlikler bulundukları bölgede, eø̛̣itim çağına kadar olan çocuklar için «çocuk bakım yurtları", eğitim çağına gelmiş çocuklar için "Yetiş̧irme yurtları" ve çeşitli işyeri, atölye, kurs binası ve sair eğitim müesseseleri kurarlar (KMÇHK m. 5/I). $\mathrm{Bu}$ yurtların ve kurulușların ișleyișlerinden birlikler sorumlu olur. lar. Ayrıca birlikler, bu yurtlarda yetiștirilmekte olan çocukların kişisel durumları ile de yakından ilgilenmek zorundadırlar. Henüz bakkinda korunma tedbiri alınmamış olmakla beraber, özel durumu icabı hakkmda acil tedbirler alnmması gerekli olan çocuklar vardır. Bu çocuklar mahallî mülkì amir tarafından geçicì olarak bir kurulușa veya bir aile yanına yerleștirilmek gerekir. Isste bu gibi çocukların durumu ile de birlikler ilgilenir ve bunların yurı giderleri birlikler tarafından karşılanır.

Birliklerin ana tüziikleri, bu birlikleri müștereken kuran il özel idareleri ve belediyeler tarafından yine birlikte hazırlanarak kabul edilir. Eğer birliği kuran özel idare ve belediyeler ayni ilden ise, valinin, ayni ilden değiller ise, içişleri bakanının onaylaması ile tüzük kesinleșir (Bel. K. 134) (62).

(62) Bilindił̧i gibi 6972 sayıl Kanunun 10 uncu maddesi gereğince, bir yerdeki il özel idaresi ile belediye birlikleri kurarlar, eger bunların kurmaları mümkün olmazsa çevredeki illerde ortaklaşa kurulur. 
Birliklerin tüzüklerinde yer alması gerekli olan hususların neler olacağı, Belediyeler Kanununda belirtilmiştir (Bel. K. 135).

1 - Birliğin adı

2 - Yönetim merkezi

3 - Yer bakımından faaliyet çevresi

4 -D Devamlı olup olmadı̆̆ı, geçici ise kaç sene için kurulduğu

5 - Birliğge dahil olan bölgesel idarelerin adları

6 - Birlik üyesi olan bölgesel idarelerin hakları, görevleri ve yetkilerinden hangilerinin birlik ve birlik yönetim ku. ruluna devir ve emanet olunduğu

7 - Birliğe dahil olan bölgesel idarelerin, herbirinin birlik meclisi için aday göstereceği üye adedi ve bu üye ade. dinin tespitine esas olan șantların kaç senede bir birlik meclisi tarafından tatbik olunacağı

8 - Birliğe dahil olan bölgesel idarelerin birliğin kuruluș ve devamındaki giderlere ne' oranda katılacağı

9 - Birliğin gelirleri

10 - Birliğe dahil olan bölgesel idarelerin ve bu bölgesel ida relere dahil olan halkın birlik kuruluşlarnndan ne şekil de faydalanacakları

11 - Birlik meclisinin senede kaç kere toplanacağı

12 - Birliğin kuruluşuna ve devamindaki faaliyetlerine esas olacak diğer hususlar

1 - Birliklerin organları :

Birliklerin başlıca üç organiarı vardır. Bunlar, birlik meclisi, birlik bașkanı ve birlik encümenidir.

a - Birlik meclisi :

Birlik meclisi birliğin faaliyetlerini kontrol etmek iuzere senede en az iki kere toplanır (Bel. K. 139). Bu toplantılarda birliğin faaliyet raporları incelenerek birlik denetlenir. Birlik meclisi en az dört sene için seçilecek üyelerden olușur (Bel. K. 140). Birlik, lere üye olabilmek̉ için belediye meclisi üyeliğine seçilebilme yete 
neğine sahip olmak gerekir (Bel. K. 140). Bu üyeleri birliğe dahil olan bölgesel idareler seçer. Her mahalli idarenin yönetim kurulu iki üye seçer (Bel. K. 140). Ayrıca bölgesel idarelerin yönetim ku. rulları birliklerin mevcut uiyelerinin yarısı kadar da yedek üye se. çer (Bel. K. 141). Birlik üyesi olan belediye ve köylerin belediye reisleri ve muhtarlan birlik meclisinin tabiî üyeleridir (Bel. $\mathbf{K}$. 144). Birlik meclisi, asıl tüzüğünün kesinleşmesinden itibaren en geç iki ay içinde birlik merkezinin bağIı olduğu ilin valisi tarafından tayin olunan günde toplantıya çağrnlır (Bel. K. 143). İlk toplantı vali tarafından açlı. Belediye meclisi üyelerine verilen yetki ve görevler, birliğin tüzüğündeki hükümleri aşmamak şartıyle, birlik meclisi üyelerine de tanınır (Bel. K. 146) (63).

\section{b - Birlik bașkanı :}

Birlik meclisi ilk toplantısında birlik başkanını, başkan vekilini ve yardımcılarını seçer. Birliğe özel idareler de katılmışsa bu durumda başkan ve başkan vekillerini birliğin bulunduğu yerdeki vali seçer. Eğer birliğe bir kaç tane il dahilse bu seçimi Içişleri bakanı yapar (Bel. K. 144). Birlige dahil olan belediyelerden birinde, başkanhtı görevi kanunen valiye verilmișse, birlik başkanhğı bu vali tarafından yapıltr. Birlik başkanı ve vekil, birlik meclisi tarafından kabul clunan bütçenin ve karar altına alınan işlemlerin uygulanıp yerine getirilmesiyle ve birlik işlerinin yönetimiy. le ilgilerirl:r (Bel. K. 143). Birlik tüzüğündeki hükümleri aşmarnak sartıyla birlik reisleri de, belediye reislerinin sahip oldukları yetki ve görevlere sahiptirler (Bel. K. 147) (64).

\section{c - Birlik encümeni :}

Birlik encümeni yeni seçilmiş olan birlik meclisi tarafından seçilen dönt kişiden oluşur. Encümenin üyeleri, birlik meclisi üyelerì arasından seçilir. Birlik başkanı encümenin tabîi üyesi ve başkanıdır (Bel. K. 145). Birlik encümeninin görevleri, birlik meclisjnin görev devresi sonunda biter. Birlik tüzüü̆ündeki hükrümleri aşmamak șartıyla birlik encümeni, belediye encümeninin sahip olduğu yetki ve görevlere sahiptirler (Bel. K. 147) (65).

2 - Birliklerin sona ermesi :

Birlikler belirli bir süre için kurulmuşlarsa, bunun tüzükle.

(63) Fazla bilgi için bk. Belediyeler Kanunu ilgili hükümleri.

(64) Fazla bilgi için bk. Belediyeler Kanunu m. 133-148).

(65) Fazla bilgi için bk. Belediyeler Kanunu m. 133-148. 
rinde gösterilmesi gerekir. Bu sürenin bitmesi ile birlik te sona erer. Eğer birlik belirli bir süre için kurulmamıs ise ne gibi şart. larla birliğin ortadan kaldırılabileceği, birliğin tüzüğ̈̈ine yazılmalı. dır. Bu şartların gerçekleşmesi halinde, birlik meclisi, birliği fes. heder (Bel. K. 137). Birlik sona erince, birlige dahil olan kurulla. rın görüş̧leri sorulur, birliğe katılma paylan ayrılır ve birlik sermayesi ve malları birlik merkezinin bulunduğu yerdeki il idare kuruluna kalır. (Bel. K. 137).

\section{B - Mahalî̀ en büyük mülkî amir :}

Korunmaya muhtaç çocuklarla ilgili olarak birlikler yanında görevli kılınan bir kişi de çocuğun bulunduğu yerdeki en yüksek mülkî amirdir. Korunmaya muhtaç bir çocuğun varlığından haberdar olan devlet, belediye ve zabita menurlarn durumu hemen o yerdeki en yüksek mülkî amire bildirmek mecburiyetindedirler. Mahallî mïlkî amir ilgili kișilere gerekli emirleri vererek çocuk hakkinda bir dosya hazurlatır (66). Ve bu dosyayı sulh mahkemesine göndererek korunma kararı alınmasını ister (KMÇHK m. 1). Ayrıca haklarında acele korunma tedbirleri alınması gereken çocuklar varsa, mủikî amir bu çocuklar hakkında hakim hüküm verinceye kadar gerekli tedbirleri bizzat alır ve onları en uygun gelecek yerlere yerleștirir (KMÇHK m. 2). Diğer taraftan mahalli mï̈lkî amir bulunduğu yerdeki birliklerin üyesi ve başkanı olduğu için bu alandaki fonksiyonu bir kat daha artmaktadir.

\section{C-Koruma ve yetiştirme kurumI a r I:}

Bunlar tedbjrler bahsinde incelendiği için burada yarıca ele alınmayacaklardır. Ancak bu kuruluşlarda personel olarak kimle rin bulunması gerektigini inceleyeceğiz.

Genel olarak her tipteki kuruluş için, muhasip, daktilo, kâtip, çocuk doktoru ve hastabakıcı, anbar ve depo memurlan, așç, bahhçıvan, makinist, şöför, usta, bekçi, kaloriferci, telefoncu, çamaşırcı, hademe gibi hizmetliler tayin edilir. Bunlar birlikler tarafından tayin edilirler. Ayrıca ilgili bakanlıklar da bir kısım personeli tayin eder. Örneğin, Millî Eğitim Bakanlığı, müzik, resim, iș ögretmenleri, eğitim uzmanları, müdürler, mü̈dür yardımclları.

(66) Fazla bilgi için bk. sh. 185 Korunma tedbirleri. 
sinuf, ders ve atölye öğretmenleri, rehber öğretmenler, küme baş. lan, psikoloğlar,

Adalet Bakanlığı, müdür, öğretmen, psikolog, eğitim uzmanları, yönetim memurları, ustalar gibi personel tayin ederler.

Yurt ve kurulușlarda çalışan personel, ister birlik, isterse bakanlıklar tarafından atansın, çalıștıkları kurumların müdürlüklerine karşı sorumludurlar.

\section{II — TEFTISȘ VE MURAKABE ORGANLARI :}

\section{A - Bakanliklar :}

Birlikler tarafindan kurulan yurtlara, bakanlıklar bir takım personel tayin ederler. Iște bu teșkilât ve personelin teftiş ve murakebesi de onu atayan bakanlı̆ga aittir. Sağlık ve Sosyal Yardım Bakanlığı, bakım yurtları, Millî Eğitim Bakanlığı da yetiștirme yurtları üzerinde kontrol ve murakabede bulunurlar (KMÇHK $\mathrm{m}$. 11). Bu teftişler ilgili bakanlıkların müfettișleri veya bu sıfatı taşıyan memurları tarafindan yapılır. Yetiştirme yurtlarında bulu. nan çocuklar çalıştırılarak bir iş sahibi edilmek için bir işyerine yerleştirilmislerse ve bu ișyeri İs Kanunu hükmüne ve 1593 sayıl Umumî Hifzısuhha Kanununun 158, 159 ve 160 inci maddeleri kapsamı içine giriyorsa, bu çocukların işyerlerindeki durumlarını da Millî Eğitim Bakanlığı teftiş eder.

\section{B-Mahallî Organlar:}

1 - Eğitim Memurları :

6972 sayılı Kanun, birliklerin ve bunlara bağlı kuruluşların iller ve yetkili kimselere teftiş ettirileceğini belirtir (KMÇHK $\mathrm{m}$. 28). Adı geçen kanunun 23 üncü maddesinde teftişi, eğitim memurlarının yapacağı ve onların hazırladığı yazılı raporun birliğe tebliğ olunarak aksaklıklarm düzeltilmesi hususunda ihtarda bulunula. cağı belirtilmektedir. Eğitim memurların, valiler tayin eder. Bunlar; sağ $l k$ işleri için, sağlık ve sosyal yardım müdürleri ve müfettişleri, yönetim, eğitim ve öğretim işleri için, millî eğitim müdürleri ve ilk ögretim müfettişleridir.

2 - Il yönetim kurullan :

Korunmaya muhtaç çocuklar alanında birliklere pek çok görevler düişmektedir. Onlar bu görevlerini icra ederken kendileri 
ile ayni bölgede bulunan diğer korunma organları ile aralannda pek çok anlaşmazlıklar çıkabilir. Bu anlaşmazlıkları inceleyip, halledecek olan ongan il yönetim kuruludur (Bel. K. 138).

3 - Teftiş ve Murakabe organı olarak mahallî Mülkî amir :

Mahallin en büyük mülkî amiri bir sevk ve idare organı olduğu kadar ayni zamanda bir murakabe organidır da. Mahallin en büyìik Mülkî amiri bizzat kendisi birliklere bağlı kuruluşları her yl gezorek teftiş eder. Bunun yanında bu kuruluşlan denetleyecek olan egitim memurlarm da vali tayin eder.

\section{C-Sayıștay:}

Birliklerin muhasebe işleri, devlet muhasebe usullerine uygun olarak görülür. 6972 sayll Kanuna göre birlǐ̆in hesaplanı, sayıștaya hesap vermekle zorunlu muhasipler tarafindan tutulur (KMÇHK m. 11). Böylelikle Sayıștay da birlikler üzerinde malî yönden dolayssiyla olan bir denetime sahiptir.

\section{D-Danıstay :}

Bir birlik çeşitli illere ait mahallî idarelerden oluşuyorsa, bu birlik ile kendisini meydana getiren mahallî idareler arasında çıkan anlaşmazlıkları Danıştay inceleyerek çözümler (Bel. K. 138) Danıştayın da böylelikle idarî Kaza organı olarak bir fonksiyonu vardir.

\section{III - DANIŞMA KURULU (Çocuk koruma genel danışma kulu) :}

Bu kurulun görevi birliklerin ylltk faaliyet raporlarını ince. lemektir. Danışma kurulu, her yıl bir defa Millî Eğitim Bakanhğında toplanı, birliklerin ylllı faaliyet raporlann inceleyerek kurulușlardaki gelişme yahut ta gerileme ve aksaklıklan tesbit eder. Aksak ve ekisik gördüğü hususların giderilmesi için alınması gerekli tedbirler hususunda tavsiyelerde bulunur (KMÇHK m. 28). $\mathrm{Bu}$ kurulun görevi daha ziyade aksaklıklarm giderilmesi hususunda ve istișarî mahiyettedir. Bu kurulların, birlikleri denetleme gibj bir görevleri yoktur fakat verdiği raporlarm onlann denetlenmesj lizerinde dolaylı bir tesiri olur. Şöyle ki, birliklerin teftis ve murakabe organları tarafindan, danıșma kurullarının verdiği müta. làalar göz önüinde tutulabilir. 
Danışma kurulu aşağıdaki üyelerden oluşur :

1 - Millî Eğitim, Sağlık ve Sosyal Yardım, İçişleri, Adalet, Millî Savunma, Çalışma, Tarım, ve Isşletmeler bakanlık lari temsilcileri

2 - Üniversite ve yüksek okul kurulușlarmndan bir pedagog, bir çocuk ve ruh hastalıkları mütehassısı, bir çocuk hu kuku ve bir sosyal hukuk mütehassisı

3 - Millî Eğitim Bakanlığınca kurulan, tayin ve tespit edi. len birliklerin onda biri nispetinde vali, belediye reisi, sağltk ve sosyal yardım müdürü, millî eğitim müdürü ve yurt müdiürleri

4 - Gerek doğrudan doğruya ve gerekse dolayısıyla çocuk koruma, bakımı, eğitimi ve sağlığı gayesine matuf olarak kurulan hayır cemiyetlerinin üçünün birer temsilcisi

5 - Büyük kuruluş ve iş sahiplerinden üç temsilci

6 - Bir hayır kurumuna bağlı olmadan önemli bir̀ bağışta bulunan veya tesis kuran şahıslardan iki kişi

Bu kurul, Millî Ë̆gitim Bakanının veya müsteşarının başkanll. ğında toplanir.

5387 saylı Kanun zamanında bir de "Il ve ilçe çơ uk koruma genel kurulu» diye bir kuruluş vardı. Bu kurul, yılda üç defa vali veya kaymakamı başkanlığı altında toplanır, ve incelemelerden sonra tavsiyelerde bulunurdu. Bunlar çocuk koruma umurnî danıș. ma kuruluna nazaran mahallî mahiyette idiler. Bu kurullar 6972 sayılı Kanunla ortadan kaldırılmışlardır.

\section{§ VIII - MALII KAYNAKLAR :}

\section{I - MECBURI MALI KAYNAKLAR :}

Bundan maksat, korunmaya muhtaç çocukların, bakım ve yetiştirilmesi bakımından her durumda faydalanılması gereken kaynak lardur.

A-Çocuğun şahsîgeliri ve ana baban in çocuğun bakimına katılmas ı:

1 - Çocuğun şahsi geliri :

Yetiştirme yurtlarmda barman çocukların kabiliyetleri oranunda birlikler tarafından ileri seviyede eğitim ve öğretimleri să̆ 
lanır. fleri seviyede ögretime kabiliyeti olmayanlar ise bir meslek ve sanat sahibi edilmek üzere özel bir fabrika veya işyerine ya da bir is ve meslek sahibi yanma yerleştirilir yahut ta birlik tarafm: dan kurulan atölyelere yerleștirilir. Bu çocuklar, buralara bir çıraklık sözleşmesi ile veya ücret karşıllığında çalışmak üzere yerleștirile. bilirler. Eğer çocuk ücret karş̧lığnnda çalış̧mak üzere yerleştirilmiş. se, çocuğun kazandığı paradan bir kısmı alıkonularak çocuğun yurt giderlerine katılma payı olarak harcanır. Geri kalan kısımdan ço cuğun harçlığı da çıkarıldıktan sonra artanı çocuk adına millı̂ bankalardan birine yatırılır. Çocuğun harçlığının ve yurt giderlerine katılma miktarının ne kadar olacağın birlik encümeni tayin eder.

Diğer yandan velâyet altında bulunan veya velâyet altında ol. madığı için kendilerine bir vasî tayin edilen çocukların șahsî mal. ları varsa, çocuğun giderleri bu şahsî malları ile karşılanır. Velâyet altındaki çocuğun masraflarının normal olarak ana baba tarafından ödenmesi gerekir. Fakat ana babanın maddî durumu yetersiz ise ve çocuğun da şahsî malları varsa bu durumda çocuğun giderleri kendi mallarından karșılanır.

2 - Ana babanın çocuğun bakımına katılmaları :

6972 saylı Kanun gereğince hakkında korunma tedbiri alınar, - bir çocuğun ana babası veya bunlardan birisi sağ ise ve yardım ede. cek kudrette ise, bunların da çocuğun bakımına katılmalan sağlantr (KMÇHK m. 3/I). Bunların çecuğun bakımına ne oranda katılacakları Medenî Kanun hükümlerine göre tayin edilir. Medenî Ka: nuna göre ģocukların bakım ve yetiş̧tirilmeleri, birlikte ana babaya aittir (MK. m. 151). Aslında koca, aile birliğinin reisidir ve Medenî Kanunun ifadesi ile karmm ve çoctukların iaşe ve ibatesini sağlamakla mükelleftir. Eğger babanın malî gücü yetersizse ve ananın da imkânları varsa bu alanda da çocukların bakım ve yetiştirilmesini sağlamak için kocasına yardımcı olur (MK. m. 152). Eğer ana baba birlikte yaşamıyorlarsa, çocukların bakımına ne oranda katılacak. Jarın hakim tayin eder (MK. m. 148/II).

Ana babası veya bunlardan birisi olan ve hakkinda korunma tedbiri alınmış olan çocuğun ana babası ile ilişkileri kesilmiş deそ̧ildir. Ana baba, çocuğun bakım ve yetiştirilmesi için gerekli masraflan yapacak veya yapılan masraflara katılacaktır. Eger ana baba bu masraflarn tamamm yüklenebilecek durumda degil iseler, masraflara ne oranda kattlacaklarmn hakim tayin eder. Bu tayin ve tespit işini çocuk hakkında korunma kararı veren hakim yapar (KMÇHK m. 3/II). 


\section{B - Kamu idare ve kuruluslarınd a n} saglanan gelirler:

1 - Millî Eğitim, Sağlık ve Sosyal Yardım Bakanlıklarının yardımlan :

6972 sayılı Kanun gereğince bu bakanliklar birliklere her tür. lï yardımı yapmakla görevlidir (KMÇHK m. 4/II). Bu maddede genel olarak ifade edilen «her türlï yardım»dan başka Kanunun çeșitli maddelerinde bakanhkların yapmakla yükümlü oldukları yardımlara değnilmektedir. Bunlar da iki kısımda incelenmelidir.

a - Birliklerde çahşan personel giderleri :

Adı geçen bakanlıklar, çocukların bakım ve yetiștirilmesi ile ilgili olarak kurulan yurt ve kuruluşlara bir takım personeli ata. maktadır. Her bakanlık, kendi kontrolu altında bulunan kurulușlara bir kısım personeli atar (67). İște bakanlıklar, atadıkları bu personelin her türlü maaş ve ücretlerini de ödeyeceklendir (KMHÇK m. 7).

b - Personel giderleri dışındaki giderler :

Personel giderleri dişındaki giderler için de adı geçen bakanliklar birliklere gerekli yardımda bulunmakla görevlidirler. Bu bakanlıklar, birlikte bir yönetmelik hazırlarlar ve bu yönetmelikteki esaslara bağh olarak bütçelerine ayrı ayrı koyacakları tahsisatı birliklere dağtturlar. Bu tahsisat büttün belediye ve özel idarelerin bütçelerine koyacakları tahsisatların toplamından az olamaz. Bu tahsisat, bütçelerinin onaylanmasından $\mathrm{iki}$ ay içinde birliklere gönderilir. Bu tahsisat, maaş ve ücret gibi personel giderleri dı̧̧ındaki giderleri karșılamak içindir (KMÇHK. m. 9).

2-Belediye ve özel idarelerin tahsisatları :

Bütün belediyeler ve özel idareler, bu kanunla kendilerine verilen görevleri yapmak ïzere bütçelerine belirli bir tahsisat koymakla mükelleftirler (KMÇHK m. 8). Bu tahsisat her yll konur ve bir yll önceki belediye ve özel idarelerin bütün diğer tahsisatlarmm en az \% 1 i olur. Bu tahsisatlar bütçelerinin onaylanmasından itibaren en az üç ay içinde ilgili birliklerin bankalardaki fon hesaplarına yatırılır. Eğer belediye ve özel idareler bu tahsisatı koymaz veya eksik koyarsa bu eksiklik giderilir. Belediye ve özel idarelerin

(67) Bu hususta bk, sh. 227, 228. 
bütçelerini onaylamakla yetkili olan makam kendiliğinden, onayLama sirasında tahsisat konulmamısssa koyar, eksik konulmussa tamamlatır.

3 - Genel ve katma bütçeli daireler, Belediyeler ve 3659 sa. yilh kanuna tabi kuruluşlar ve sermayesinin yarısından fazlası devlete ait olan diğer kuruluşların tahsisatlan:

6972 saylı Kanuna göre bu sayllan kuruluşlar, korunmaya muhtaç bir çocuğu hizmetlerine almışlarsa, bu çocuğu

$$
\begin{aligned}
& \text { a - beslemek, } \\
& \text { b - giydirmek, } \\
& \text { c - barndirmak }
\end{aligned}
$$

zorundadırlar ve bunun için gerekli malî tahsisatları bütçelerine koymakla yükümlüdürler (KMÇHK m. 8).

\section{4 -. Mülhak ve Mazbut vakıflarn yardımları :}

Bunlar vakfiyelerinde çocuklara yardım için tahsisat koymuş. lar ise bunların adına mütevelliler ve vakuflar genel müdürleri ge. rekli yardımı yapacaklardır (KMÇHK m. 25/ç).

\section{II - DIĞER MALI KAYNAKLAR :}

$$
\begin{gathered}
\text { A Oózel fabrika, işyerleri, iş ve mes lek } \\
\text { sahiplerinin kattlması: }
\end{gathered}
$$

Bu gibi yerlere bir meslek ve sanat öğrenmek üzere verilen çocuklarm bakılıp yetiștirilmeleri için gerekli masraflar -besle nip giydirilmesi ve barındırılmasıyerlerin sahiplerine aittir. Fakat bu hususta kendilerine kesin bir mükellefiyet yükletilmemiștir. Eğer imkânları varsa bununla yü. kümlüdürler, imkânları yoksa bu masraflar çocuğun bağlı bulunduğu birlik tarafından karşılanır (KMÇHK m. 17).

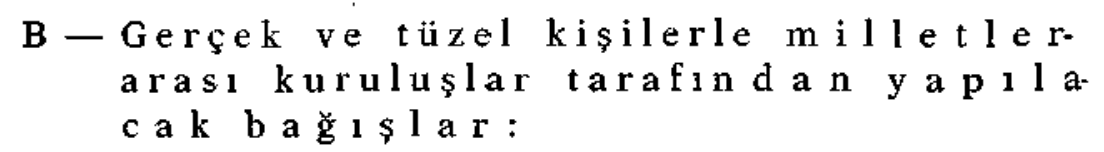

Korunmaya muhtaç ̧̧ocuklar için bağışta bulunacak olan bu gibi şahıslar, bu bağışları birliklere yaparlar. Bu bağışlar, para ve. ya eşya șeklinde olabilir. Eşya ise, menkul veya gayrimenkul ola. bilir. Eşya olarak yapılan bağışlarm değerlerinin tespiti, birlikler tarafından yapılır (KMÇHK m. 25/ç). 


\section{C-Bakim ve yetiştirme yurtları tarafın- dan veya bunlar yararina verilen müsa. mere ve yapilan gösterilerden elde edi- len gelirler:}

Eğer böyle bir faaliyet bahis konusu ise bunlardan elde edi. Ien gelirler, korunmaya muhtaç çocuklar için harcanır (KMÇHK m. 25/c) . Gerek bu gelirler, gerekse yukarida bahsedilen diğer ge. lirler her türlü vergi, resim ve harçlardan muaftır.

\section{$S O N$ U Ç}

Korunmaya muhtaç çocuklar hakkında Kanunda yeterli görülmeyen hususlara sırası geldikçe değinilmiștir. Bunlardan bașka olarak şu temennilerde de bulunmak gerekir.

1 - 6972 sayılı Kanun ve Medenî Kanun, korunmaya muhtaç bir çocuğun varlığından haberdar olan devlet, belediye ve 7.a. bıta memurlarnm durumu, gerekli kișilere ithbar edeceklerini bildirmektedir (68). Bu memurlar, böyle bir çocuğun varlığından genellikle görevlerini yaptıkları sırada haberdar olurlar. Halbuki toplưm içinde o kadar korunmaya muhtaç çocuk vardır ki bunların pek azının, bir kısım devlet memurlarının yaptıklan işlemler. le ilgileri vardır. Onun için toplum içindeki korunmaya muhtą̧ cocukların taranıp ontaya çıarılmasını sağlayacak ve birliklere bağlanacak bir teşkilàt kurılması gerekir.

2 - Ana babası olmayan cocuklar hakkında sulh mahkemesi görevlidir (69). Eğer Medenî Kanunun vesayetle ilgili hükümlerine uygun olarak sulh mahkemesi yanında asliye mahkemesi de görevli kılınırsa, daha sıkı ve kademeli bir kontrol sağlanmış oluraur.

3 - 6972 sayılı Kanun, belediye ve özel idarelerin birlikleri müștereken kurmaları gerektiğini belirtir. Eğer bunların kurmaları mümkün olmazsa çevredeki illerle ortaklaşa olarak kurarlar. Ĕger bu da mümkün olmazsa kurulmuş olan diğer birliklere üye dlarak girerler (KMÇHK m. 10). Bu hüküm yeni birliklerin ku. rulmasın önleyici mahiyettedir (70). Çünkü ontaklaşa tahsisatları birlik kurmaya yetmeyen ve çevredeki diğer illerle de birlik ku. ramayan belediye ve özel idareler kurulmuş olan birliklere üye

(68) Bu hususta bk. sh. 184.

(69) Bu hususta bk. sh. 189.

(70) Bu hususta bk. sh. 191.

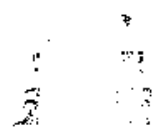


olarak katılmaktadırlar. Halbuki, yunt çapında ne kadar çok bir lik bulununsa, korunmaya muhtaç çocuklar meselesine o kadar çok yardım edilmiş olunur. Bunun için bir hüküm koyup, «Belirli bir sïre içinde koymaya mecbur oldukları tahsisatları ile birlik kuramayan veya çevredeki illerle ontaklaşa olarak ta bunu yapa. mayan belediye ve özel idarelere, Millî Eğitim ve Sağlık ve Sosya Yardım Bakanlığı tarafından gerekli malî yardım yapılarak birlik kurulması sağlanır» denmelidir.

4 - 6972 say1h Kanunun 1 inci maddesinde korunmaya muh. taç çocuklar tarif edilirken (d) şlkkında, «Ana babası tarafından ihmal edilip, fuhșa, dilenciliğe, alkollii içkileri ve uyusturucu mad. deleri kullanma alıskanlığına, serserileğe yöneltilen çocuklar» dan bahsedilmektedir. Hemen sonra bu çocuklar için sulh mahkeme sinin görevli olduğu bildirilmektedir. Fakat bu sayılan çocuklar ana babaya sahiptirler ve görevli mahkeme bahsinde de incelendi. ği gibi ana babası olan çocuklar hakkında asliye mahkemesi gö revlidir. 6972 sayıl Kanunun 1 inci maddesi böylelikle bir ikilik ortaya çkarmaktadır, bunun düzeltilmesi gerekir.

5 - Yetiștirme yurtlarında barınan çocuklar, tucret karşlly. ğında bir yerde çalıșmakta iseler, Bunların kazandıkları paralar. dan, yurt giderlerine katılma payı, birlik encümeni tarafundan tes: pit edilerek alıkonulur. Fakat bu işin hangi esaslạr dahilinde ya. placağı belintilmemiștir. Birlik encümeni bunu yaparken ne mik. tanda ve hangi ölçüleri göz önüinde tutarak yaptığını açıkça bir rapor halinde hazırlayıp, çocuk hakkında barındığı yurtta tuıulacak bir dosyaya koymalıdır.

6 - Korunmaya muhtaç çocukların, Sağlık ve Sosyal Yardım Bakianlıgının emrine tahsis edilecek bir sosyal yardım fonundan yararlanabilmeleri için 12.8 .1961 de yürürlüğe giren yönetmelikte bahis konusu olan dernekler içine birliklerin de katılmasını sağ yacak bir değisşiklik yapılmalıdır (71).

7 - Her yıl memleket çapında kampanyalar açılmalı, gösteriler ve ögretici faaliyetler diuzenlenerek korunmaya muhtaç çocuklar meselesi gerektiği gibi halka anlatılmalıdır (72).

(71) Bk. SUNAY, Cevdet: Kurban bayramı ve korunmaya muhtaç çocuklar, Istanbul Bayram Gazetesi, 22.3.1967, sh. 1 ve 11.

(72) Bk. SUNAY, Cevdet : Kurban bayramı ve korunnaya muhtac çocuklar, Istanbul Bayram Gazeteși, 22.3.1967, sh. 1 ve 11 . 
8 - Bakım ve yetiştirme yurtlarında, malî imkânlar sağlana. rak eğitim ve yetiștirme ișlerinden anlayan yüksek tahsilli uzmanlara meselâ «Sosyal Hizmetler Akademisi» mezunlarına görev verilmelidir (73).

(73) Bk. SUNAY, Cevdet: Kurban bayramı ve korummaya muhtaç çocuklar, İstanbul Bayram Gazetesi, 22.3.1967, sh. 1 ve 11. 